\title{
Healing wounds, instilling hope: The Tanzanian partnership against obstetric fistula
}

Thoraya Ahmed Obaid

Erica Chong

Population Council

Follow this and additional works at: https://knowledgecommons.popcouncil.org/departments_sbsr-pgy

Part of the International Public Health Commons, Maternal and Child Health Commons, Obstetrics and Gynecology Commons, Social and Behavioral Sciences Commons, and the Women's Health Commons How does access to this work benefit you? Let us know!

\section{Recommended Citation}

Obaid, Thoraya Ahmed and Erica Chong. 2004. "Healing wounds, instilling hope: The Tanzanian partnership against obstetric fistula," Quality/Calidad/Qualité no. 16. New York: Population Council. 
Healing Wounds, Instilling Hope:

The Tanzanian Partnership

Against Obstetric Fistula

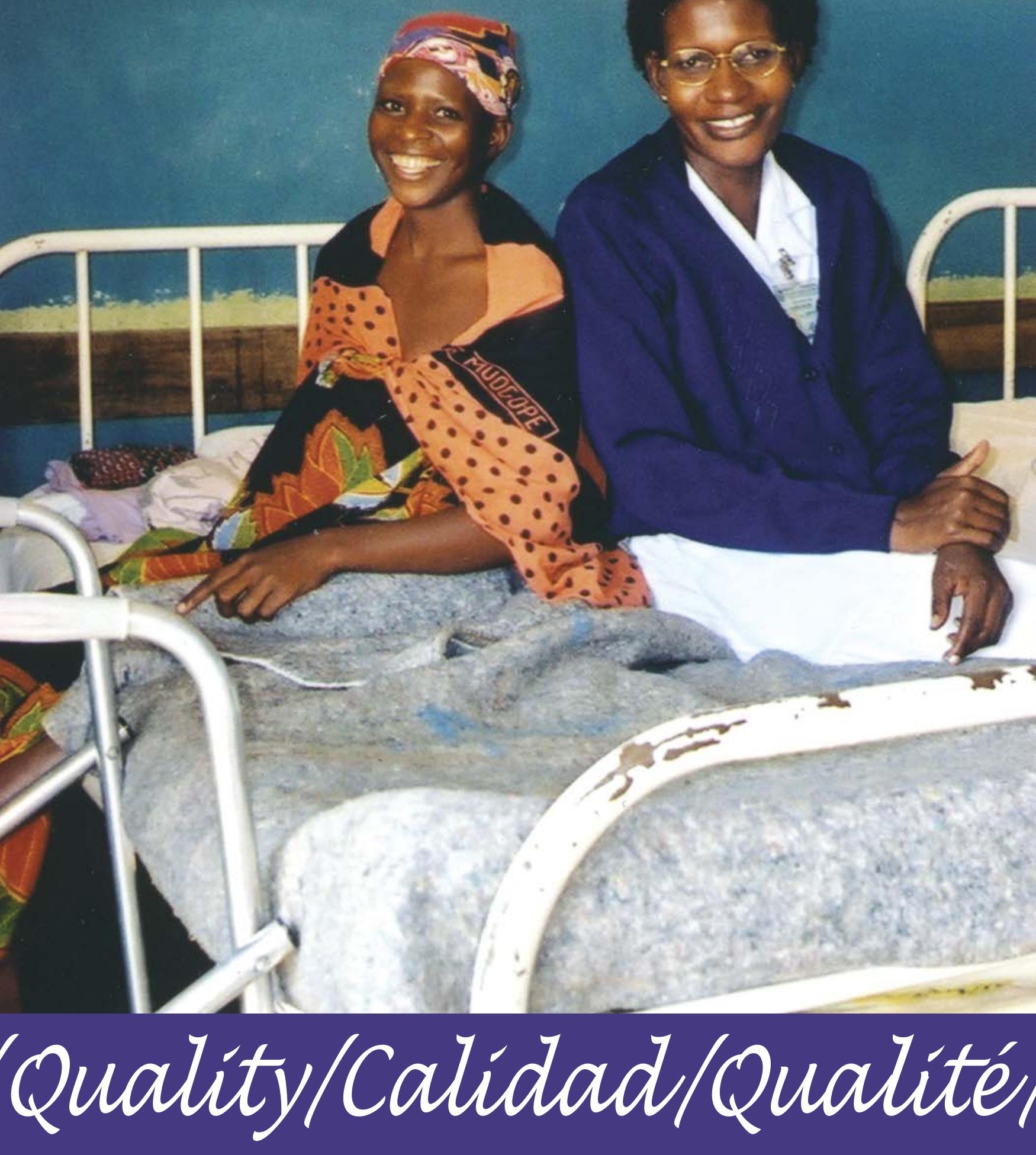




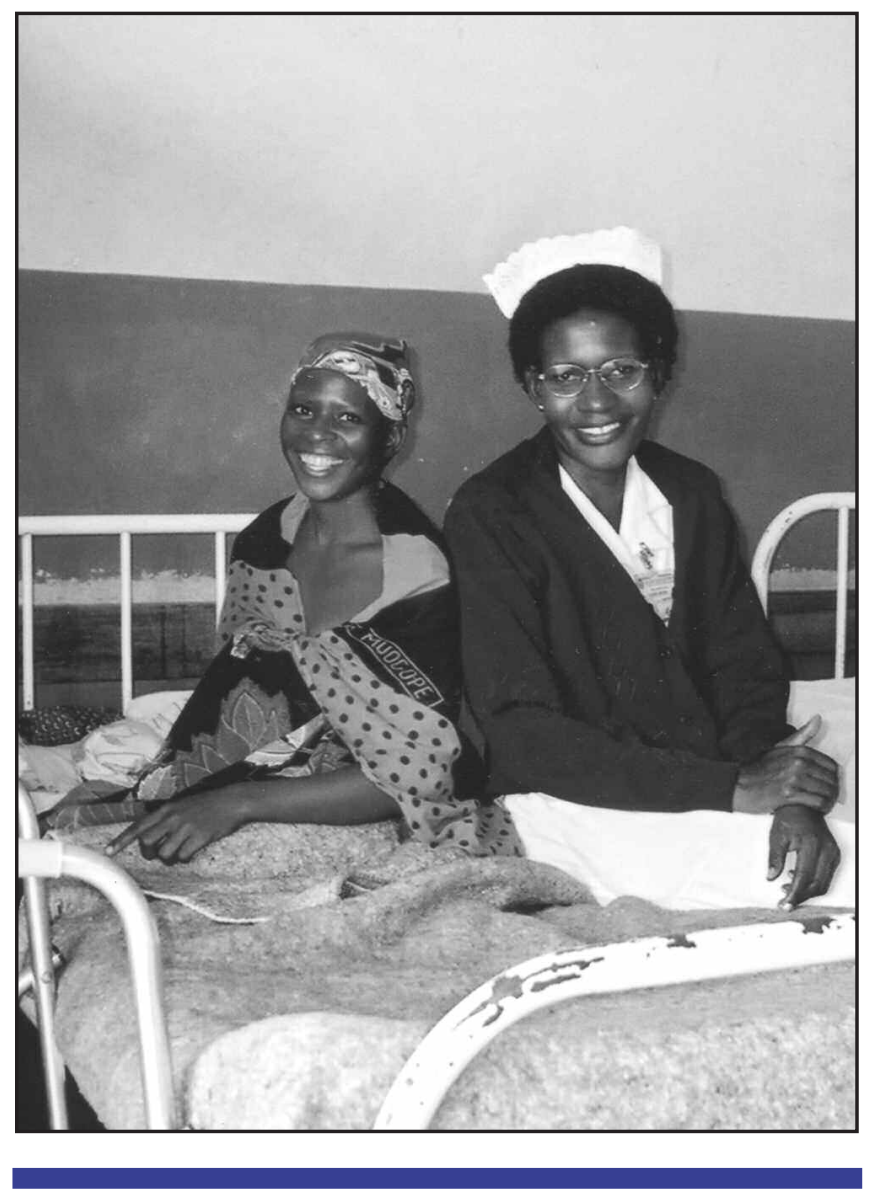

Healing Wounds, Instilling Hope: The Tanzanian Partnership Against Obstetric Fistula 
Quality/Calidad/Qualité, a publication of the Population Council, highlights examples of clinical and educational programs that bring a strong commitment, as well as innovative and thoughtful approaches, to the issue of high-quality care in sexual and reproductive health. The series is based on the philosophy that people have a fundamental right to respectful treatment, information, choice, and follow-up from reproductive healthcare providers.

$Q / C / Q$ documents projects that are making important strides in one or more of the following ways: broadening the choice of methods and technologies available; providing the information clients need to make informed choices; enabling clients to become more effective guardians of their sexual and reproductive health; making innovative efforts to increase the management capacity and broaden the skills of service providers at all levels; combining health care, family planning, and related services in innova- tive ways; and reaching underserved and disadvantaged groups.

Projects are selected for documentation by an advisory group made up of individuals who have a broad range of experience with promoting quality of care in sexual and reproductive health. None of the projects documented is being offered as a model for replication. Rather, each is presented as an unusually creative example of values, objectives, and implementation. These are learning experiences that demonstrate the self-critical attitude required to anticipate clients' needs and find affordable means to meet them. This reflective posture is exemplified by a willingness to respond to changes in clients' needs as well as to the broader social and economic transformations affecting societies. Documenting the critical choices these programs have made should help to reinforce, in practical terms, the belief that an individual's satisfaction with sexual and reproductive health services is strongly related to the achievement of broader health and population goals.
INNFPA 100

Publication of this edition of Quality/Calidad/Qualité is made possible by support provided by the United Nations Population Fund (UNFPA); by the Robert H. Ebert Program on Critical Issues in Reproductive Health of the Population Council; by the Ford Foundation; and by the Gender, Family, and Development Program of the Population Council. Statements made and views expressed in this publication are solely the responsibility of the authors and not of any organization providing support for $Q / C / Q$.

\section{(2) Population Council}

The Population Council is an international, nonprofit, nongovernmental organization that seeks to improve the well-being and reproductive health of current and future generations around the world and to help achieve a humane, equitable, and sustainable balance between people and resources. The Council conducts biomedical, social science, and public health research and helps build research capacities in developing countries. Established in 1952, the Council is governed by an international board of trustees. Its New York headquarters supports a global network of regional and country offices.

Population Council, One Dag Hammarskjold Plaza, New York, NY 10017 USA

tel: (212) 339-0500 fax: (212) 755-6052 e-mail: qcq@popcouncil.org

Cover photograph by Erica Chong.

Issue No. 16 ISSN: 1097-8194

Copyright (C) 2004 The Population Council, Inc.

Any part of this publication may be copied or adapted to meet local needs without permission from the Population Council, provided that the parts copied are distributed free or at cost (not for profit) and that the source is identified. The Population Council would appreciate receiving a copy of any materials in which the text is used. 


\title{
Introduction
}

\author{
by Thoraya Ahmed Obaid
}

In many parts of the world, women learn to accept the risk of illness, injury, and death as the price they must pay for giving birth; indeed, half a million women and girls prove this through their deaths every year. Among the women who survive childbirth each year, many find their health compromised. Tragically, these women suffer needlessly, because most childbirth-related complications are preventable. That such high maternal morbidity persists in the twenty-first century reflects the enormous gaps that remain between the developed and developing world, particularly in the quality and availability of maternal health care.

A particularly poignant example of the disparities in care is the problem of obstetric fistula (see box on Obstetric Fistula and Its Medical Consequences). Obstetric fistula has all but disappeared in wealthier parts of the world, yet every year, the World Health Organization has estimated that at least 50,000 to 100,000 women and girls-virtually all living in poor communities-develop fistula. The condition appears to be particularly common in Africa.

\section{Poverty is the Root Cause}

Although fistula is most often caused by obstructed labor, vulnerability to this condition begins long before the moment of delivery and has its roots in poverty. Stunting resulting from malnutrition may lead to inadequate pelvic growth and increase the risk of obstructed labor. Similarly, girls who are married young, often for economic reasons, frequently become pregnant before completing their own growth. Older women who have been weakened by

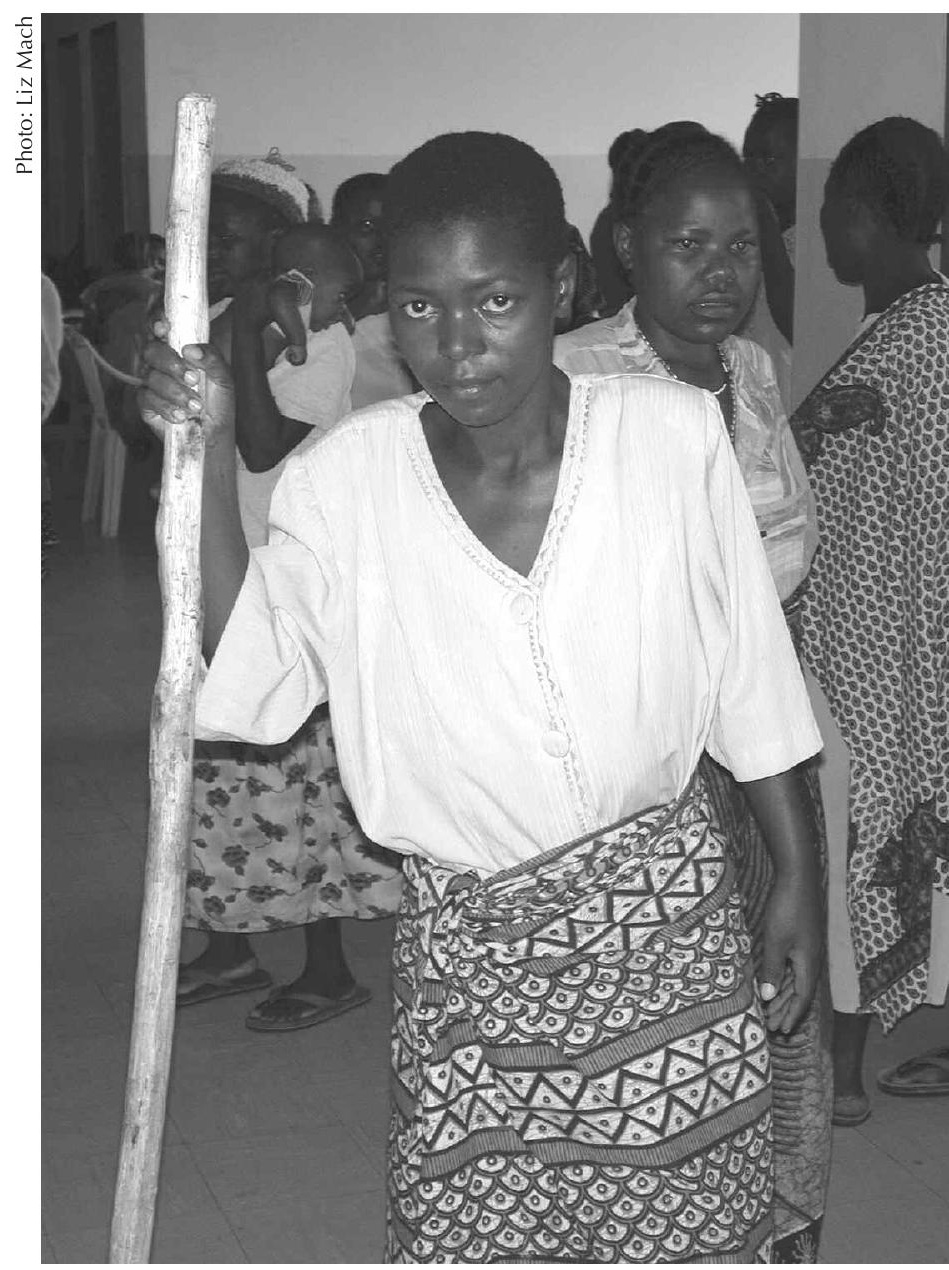

Women with obstetric fistula suffer a number of medical consequences, including incontinence. The social ramifications, however, may be even more traumatic, often involving the loss of social and economic support systems, in addition to the death of the baby in childbirth. 
many pregnancies may also be at greater risk. Moreover, women in these circumstances are likely to live in settings in which their own health is a low priority and their access to health-care services is sorely inadequate.

The consequences of fistula are severe. Women with fistula suffer from a number of medical problems, including incontinence, but the social ramifications may be even more traumatic. Typically, a woman with fistula must

\section{Fistulae can be repaired}

surgically even months or years

after they occur, and most or all

symptoms can thereby be

eliminated or alleviated, so

that the woman can regain her

dignity and a normal life.

deal not only with the death of her baby but also with the loss of social support networks. She is liable to be rejected by her husband because of her incontinence and unclean state; sometimes even her birth family subsequently refuses to take her back. She is effectively excluded from community life, and she may be ridiculed or even blamed for what has happened to her. Despite these hardships, the women who cope with fistula often exhibit extraordinary courage and resilience.

\section{Fistula Need Not Mean Lifelong Suffering}

Fistulae can be repaired surgically even months or years after they occur, and most or all symptoms can thereby be eliminated or alleviated, so that the woman can regain her dignity and a normal life. In comparison with the need, however, fistula-repair services and skilled surgeons are still few in number. Many countries are laboring to improve and extend health care in a context of fierce competition for scarce resources (particularly surgeons); in such settings, attending to a woman who has coped for years with fistula is often a low priority. Moreover, most girls and women with fistula are unaware of the possibility of repair and, in any case, lack the resources to pay for treatment or even to travel to a surgical center.

\section{Fistula is Preventable}

For prevention, access to health services is crucial: A combination of high-quality antenatal care and screening, skilled attendants at delivery, prompt treatment for emergencies, and good postnatal care will save mothers' lives and prevent many disabilities, including obstetric fistula. Eliminating obstetric fistula, however, is a task beyond the scope of health services alone. It requires an integrated approach, with support and commitment from individual countries and the international community. It also requires full partnership with communities to promote prevention and repair. Educational efforts are necessary to end stigma and to ensure that awareness of prevention strategies reaches families and communities. An integrated prevention strategy must include initiatives that enhance female equity with regard to health-care access, schooling, income generation, and autonomous decisionmaking. Thoughtful approaches to the improvement of services and fostering of change are particularly important for rural and remote areas. Women whose fistulae have been surgically repaired may also require social support and services to help them to return to their communities. 


\section{Tanzania: A Case Study of National Efforts}

The following case study describes the efforts under way in Tanzania to eliminate obstetric fistula. Leaders within a hospital program, nongovernmental organizations (NGOs), and the Tanzanian government are working together to identify and treat women with fistula while simultaneously seeking to identify and address its root causes. The study narrates the stories of the women and girls who find their way to Bugando Medical Centre, and of the dedicated hospital staff, community advocates, and government officials who understood the need to treat and prevent fistula and who are extending themselves to respond to that need.

\section{UNFPA and its}

\section{Partners-A Global Initiative}

In 2003, the United Nations Population Fund (UNFPA), recognizing fistula as a long-neglected women's health concern, launched a global Campaign to End Fistula. Working in partnership with UN agencies, governments, nongovernmental organizations, medical institutions, and individual experts, the campaign seeks to raise awareness, assess needs, expand treatment, and address the causes of obstetric fistula. Recent studies conducted in Bangladesh and Yemen have shown that obstetric fistula is a problem in countries outside Africa, and the campaign has responded by expanding efforts to these regions as well. UNFPA and its partners have completed needs assessments in 14 countries, and they plan to complete them for all countries at risk by 2005. Currently, UNFPA is providing support to more than 20 countries, mostly in sub-Saharan Africa and South Asia. In all regions, UNFPA, together with its partners, is developing nation-

\section{Preventing and treating obstetric fistula is not only a matter of medical practice; it is also a matter of human rights, including the right to adequate reproductive health care.}

al strategies to address the identified gaps in prevention and treatment of obstetric fistula and is supporting implementation of these plans.

The key to action is not to be overwhelmed by the scale and complexity of the problem. Each surgery means the possibility of a new life for one woman. Each successful repair shows the community that fistula is not a life sentence and increases confidence in healthcare services. Each midwife who is trained and each facility that is upgraded to provide high-quality emergency obstetric care contributes to the prevention of this condition. Each educational effort in the community can raise the awareness of more families concerning the importance of ensuring that women receive the care they need.

Preventing and treating obstetric fistula is not only a matter of medical practice; it is also a matter of human rights, including the right to adequate reproductive health care. Women and girls around the world deserve the time, resources, and commitment necessary to achieve this goal. The time has come to replace continued neglect with effective action, ensuring hope and dignity for each woman who gives birth. 


\section{What is Obstetric Fistula?}

Obstetric fistula refers to a hole that tears open during labor in the tissue between the vagina and bladder or between the vagina and rectum, or both. Typically, in developing countries, the immediate cause of fistula is obstructed labor related to cephalopelvic disproportion (a situation in which the mother's pelvis is too small to allow for safe passage of the baby's head). In settings with adequate access to emergency obstetric services-particularly cesarean section-providers can manage most cases of obstructed labor safely. Where cesarean section is not available or is not provided in a timely manner, sustained pressure from the baby's head can cause the vaginal tissues to die and slough away, resulting in a fistula, or hole in the tissue. In nearly every case of fistula, the obstructed labor also causes neonatal death.

Women with fistula may suffer a range of medical consequences, including incontinence, bladder infections, and genital ulcerations; as many as one in five women may also suffer "foot drop," involving nerve damage to one or both legs that impairs the ability to walk (UNFPA and EngenderHealth 2003). For many women, the normal menstrual cycle is disrupted, and some are no longer able to conceive.

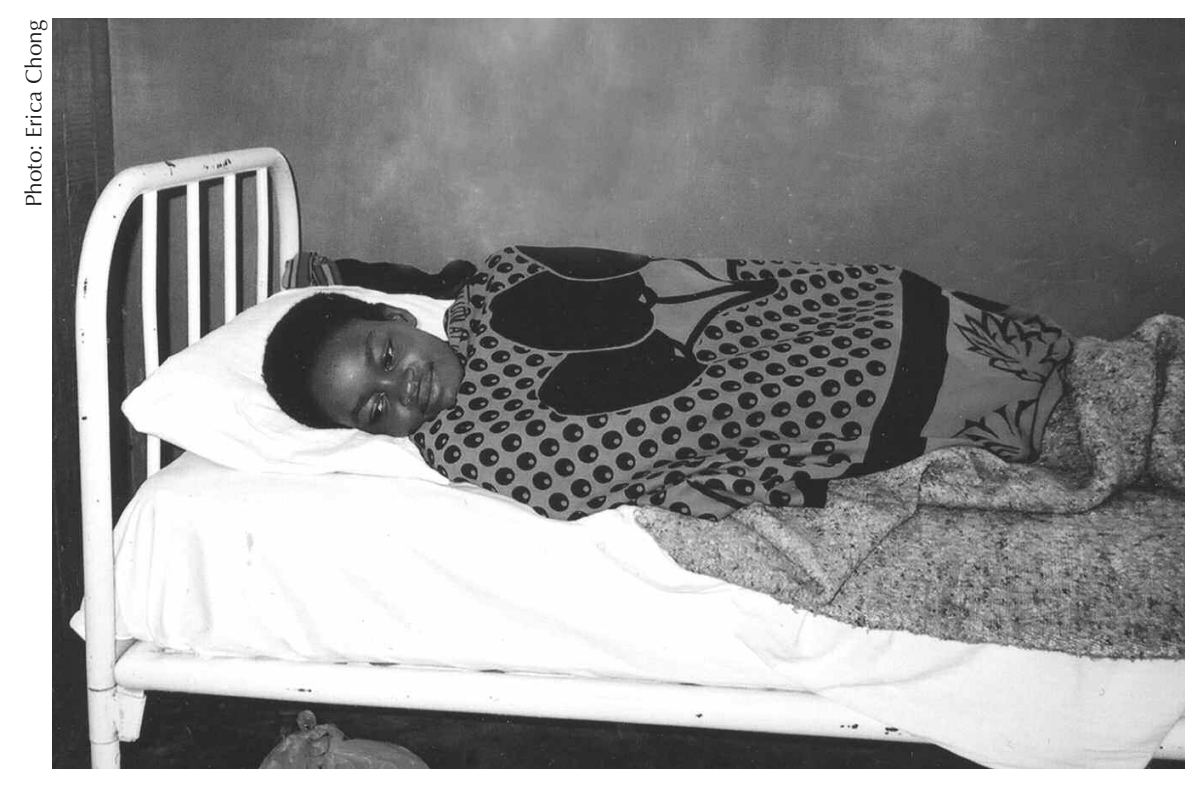

\section{Reference}

United Nations Population Fund (UNFPA) and EngenderHealth. 2003. Obstetric Fistula Needs Assessment Report: Findings from Nine African Countries. New York: United Nations. 


\title{
Healing Wounds, Instilling Hope: The Tanzanian Partnership Against Obstetric Fistula
}

\author{
by Erica Chong
}

A girl came to the hospital who had both a rectal and a vaginal fistula. When the [doctor] examined her, it was one huge hole; the urethra, the vagina, the rectum, everything was jumbled together. A visiting surgeon worked an hour and a half to repair the bladder and reconstruct the urethra. She took a break, shook the stiffness out of her shoulders, conferred with the other surgeons, and resumed the procedure. Another hour and a half later, she had reconstructed the rectum and anal sphincter. By the time she started rebuilding the vagina, word of the surgeon's skill had spread to the other operating theaters and a few surgeons had come in to observe the procedure. While the surgeon worked, an awed silence prevailed, but when she finished, the excitement spilled over-some people were clapping, some laughing, unable to believe what they had witnessed. [One doctor] started singing a hymn, clear and beautiful, and as people joined in, the sound swelled and filled the room. I began to understand the magnitude of what it was we could accomplish here, how we could fundamentally improve these women's lives.

—Liz Mach, Bugando Medical Centre

Tanzania is an East African country of spectacular beauty, perhaps best known to outsiders for its wealth of wildlife in areas like the Serengeti National Park and the Ngorongoro Crater. Although Swahili and English are the official languages, the country's 35 million people belong to more than a hundred ethnic groups, each with its own language and customs.

For all its natural wealth, Tanzania is struggling with the challenges of development; about 60 percent of the population live on less than US \$2 a day (UNDP 2003), and life expectancy has fallen to 43 years (World Bank 2003). Government health expenditure is $\$ 6$ per capita, and the country has only four doctors per 100,000 people (compared, for example, with Namibia, which has 29 doctors per 100,000) (UNDP 2003). Tanzania's once strong educational system has lost momentum in recent years. Although the abolition of primary-school fees has increased enrollment significantly, the costs associated with books, uniforms, and various informal payments prevent some children from going to school. Only about 5 percent of children of the appropriate age group are enrolled in secondary school (PRB 2000).

Girls are often pulled out of school earlier than boys, leaving them with fewer skills with which to earn their livelihood and increasing the likelihood that they will engage in risky sexual behavior for economic survival. Poverty also puts pressure on parents to marry off their daughters early to avoid the costs of rearing them. Although the average age at first marriage is 18.3 years in Tanzania (PRB 2000), the minimum legal age of marriage is 15 for girls and 18 for boys, and it is not uncommon for girls to be married at 15 or 16 .

In a society that still values women primarily for their childbearing capacity, girls are pressured to become pregnant 
as soon as possible after marriage; contraception before the first birth is not a feasible option. Thirty-nine percent of 18-year-old girls are mothers already or are pregnant with their first child (PRB 2001). Unfortunately, many of such early pregnancies result in poor outcomes: Unsafe induced abortion and childbirth result in the deaths of 7,500 to 15,000 Tanzanian girls and women each year, and an additional 150,000 to 450,000 suffer from disabilities due to pregnancy-related complications (TPP 2003). ${ }^{1}$

One of the most devastating complications of childbirth is obstetric fistula. As described in the box on page 4, fistula is characterized by constant leaking of urine and/or feces and typically is

\section{Because arranging travel to deliver}

in a hospital is difficult, many

women give birth at home. When

Rhobi's baby did not come, she

walked or sat on a bicycle for 22

kilometers, from where clinic staff

drove her to a hospital. By the

time she had a cesarean section,

her baby had already died and

Rhobi had developed a fistula. learn that fistula can be treated and who manage to secure the funds for the repair. Survey data are difficult to collect because of the stigma associated with the condition, the effort involved in reaching the remote areas where many of those with fistula live, and because the poor of Tanzania are largely voiceless. Nonetheless, as many as 1,200 new cases of obstetric fistula are estimated to occur yearly in Tanzania. In 2000-01, about 700 girls and women underwent surgical repair of the condition, creating a backlog of some 500 women in one year alone (WDP 2002). Multiply that number by the decades in which women received no treatment, and the potential backlog is immense.

\section{Causes of Fistula}

In Tanzania, poverty provides the basis for poor maternal and reproductive health outcomes in general and for factors specifically relating to the prevalence of fistula. Malnutrition and early childbearing contribute independently to the likelihood of cephalopelvic disproportion. Malnutrition begins early and has longlasting effects; among children younger than five, nearly one-third are underweight, and nearly half are of shorter than average height for their age (UNDP 2003). Although early childbearing is not as common in Tanzania as it is in other countries with high rates of fistula (for example, Ethiopia and Nigeria), more than one in four Tanzanian girls give birth before they are 18 .

Difficulty in securing transportation prevents many women from giving birth in a health-care facility. Seventy-eight percent of the population live in rural areas (UNDP 2003), and few families have access to a vehicle or can easily afford transportation. Moreover, girls and

\footnotetext{
Abortion is illegal in Tanzania except to save the mother's life. The procedure is therefore performed clandestinely, often with disastrous outcomes.
} 


\section{Barriers to Accessing Care}

Women delay or avoid going to the hospital for delivery for several reasons. The most common are lack of funds for health-care costs and transportation, long distances to health-care facilities, a lack of decisionmaking power, and ignorance about the complications that can arise during labor.

Ndebele was 19 years old when she developed a fistula. ${ }^{2}$ She was sick frequently during her pregnancy and wanted to deliver at a hospital, but her mother-inlaw refused to let her do so. At seven months, Ndebele went into labor and delivered a stillborn baby at home. A fistula had developed during the prolonged labor, and she began leaking urine two days later.

Rhobi had had three stillborn babies by the time she was 19, and her last labor resulted in a fistula. She was living in rural western Tanzania, far from any skilled provider. After encountering difficulties in trying to deliver at home, she walked and sat on a bicycle for 22 kilometers until she reached the closest health center. The staff were unable to help her, so they put her in the back of a jeep and drove her 25 kilometers to the nearest hospital, where the doctor performed a cesarean section. Rhobi had been in labor for days, however, and her baby was already dead. She had developed a fistula, but nobody at the local hospital knew how to repair it, so she stayed on the ward for months.

Mwasiti was 22 years old when she became pregnant. Her boyfriend wanted to marry her, but her father refused to allow the match. During her pregnancy, Mwasiti visited the antenatal clinic five times, where she was examined and given malaria prophylaxis and iron tablets. Her parents decided she should deliver at home because the hospital was too expensive and too far away. After being in labor for three days, Mwasiti walked to the government hospital, at a distance of ten kilometers. When she arrived, the doctor was not available, and the nurses didn't know how to help her. By the time the doctor was able to see her and perform a cesarean section, her baby was dead. She began leaking urine several days later.

Bahati was 28 years old when she delivered her fifth child. She had become pregnant for the first time at 21 , at which time she married her boyfriend and moved in with her in-laws. Her four previous pregnancies were all delivered at home, so she saw no reason to go to the hospital to deliver her fifth. During her four visits to the antenatal clinic, she received tetanus vaccinations and iron tablets. After being in labor for two days, the traditional birth attendant who was assisting her told her to go to a hospital. By the time Bahati got to the hospital where a vacuum extraction was performed, her baby was dead. Bahati began leaking urine while she was still at the hospital, but she was not catheterized nor did anyone explain to her what had happened.

women often do not have a say in decisions regarding their health care. Typically, their mothers, mothers-in-law, and husbands control such matters. Even in cases of difficult labor, a woman may lose precious time because she must wait for her husband to return home from work to obtain his permission to seek help or ask him to pay for transportation to the hospital. Although most women manage to secure antenatal care (the median number of visits is four), arranging travel for delivery is more complicated. The distances may be greater and the date cannot be anticipated and planned for in advance.

\footnotetext{
${ }^{2}$ The names given in the following examples are fictional to protect the individuals' privacy.
} 


\section{Living with Fistula}

Ndebele's memories of the period after her labor are hazy. She is adamant that her mother-in-law is a witch doctor and bewitched her. Her parents took her back home to care for her and treated her well, despite her constant leaking of urine. Friends and neighbors visited her often, and some cried to see her in such a condition. Ndebele is furious with her husband for not standing up to his mother while she was pregnant, and for not visiting her once at her parents' home. She heard that he has married another woman.

Mwasiti's mother and sister were very supportive after she came home from the hospital. Others were not so kind: Her uncle and her sister-in-law ridiculed her, and her neighbors isolated her. Her boyfriend had supported her while she was pregnant, but stopped communicating with her after she developed a fistula. Because of moderate paralysis in one leg from nerve damage that she suffered during her prolonged labor, Mwasiti found it difficult to walk. She could no longer help out in the field and stopped going to church.

Already grieving for her baby and adjusting to life with a fistula, Bahati was harassed by neighbors who blamed her for losing the child, claiming she killed her child because she was afraid to deliver (as "proved" by her prolonged labor and her need to go to the hospital). Soon after she returned home, her husband became ill. He was taken to the hospital, where he died two weeks later. Bahati remained with her in-laws, but they treated her poorly. They withheld her food and stopped speaking to her altogether. After three months of this treatment Bahati packed up her children and moved back to her parents' home. There she was not stigmatized. Her own family sympathized with her misfortunes, and old neighbors came to visit her. Her leaking, however, was too severe to permit her to travel outside the immediate vicinity of her house, and she was highly conscious of the bad odor caused by her condition. Bahati became deeply depressed about the deaths of her husband and child and about her fistula. She gave much thought to how she could help herself.

As described above, fistula has extreme health consequences for girls and women. The constant leaking of urine and/or feces causes a terrible odor and contributes to genital skin ulcerations, and frequent infections. Some women also suffer impaired ability to walk ("foot drop $^{\prime \prime}$ ), and some cannot conceive. Tanzanian women with fistula also suffer from the emotional and economic sequelae that typically accompany fistula: grief related to losing the baby, shame, ridicule, isolation, and, not in- frequently, abandonment by husbands, family, friends, and community members. Many are no longer able to continue working, and most are too embarrassed (or not allowed) to participate in such aspects of community life as religious services and celebrations. Nevertheless, like those with fistula elsewhere, Tanzanian women often display an impressive resourcefulness and strong determination to sustain themselves and their families and to seek medical care. 
For years, many health professionals in Tanzania have been concerned about fistula patients but were unsure how to approach this widespread problem. In the mid-1990s, a series of events brought together several individuals who shared a commitment to address this long-neglected condition. They mounted the Fistula Project at the Bugando Medical Centre. Some of the project's founders subsequently assumed new roles in the civil sector and government and have continued to address the problem of fistula. This issue of $Q / C / Q$ presents the story of the Bugando Medical Centre and its current partnership with the Women's Dignity Project (a nongovernmental organization) and the Tanzanian Ministry of Health to improve and expand fistula surgical repair services, preventive measures, advocacy efforts, and training at the community, institutional, national, and international levels.

\section{Starting from Scratch}

\section{A Serendipitous Meeting}

Dr. Balthazar Gumodoka, director of the Fistula Project, has been practicing medicine since 1975. He first became interested in fistula during his obstetrics/gynecology training at Muhimbili hospital in Dar es Salaam, where one of his professors demonstrated a fistula repair. Appointed to a hospital in the Mara region in 1982, Dr. Gumodoka tried to apply what he had learned at Muhimbili, but the hospital lacked adequate facilities to help those fistula patients who were admitted.

After five years, Dr. Gumodoka was transferred to the Bugando Medical Centre in Mwanza. Bugando is the secondlargest referral hospital in Tanzania, with 850 beds and about 800 staff; it serves an area of approximately 10 million people. Encountering better facilities, Dr. Gumodoka decided to provide fistula

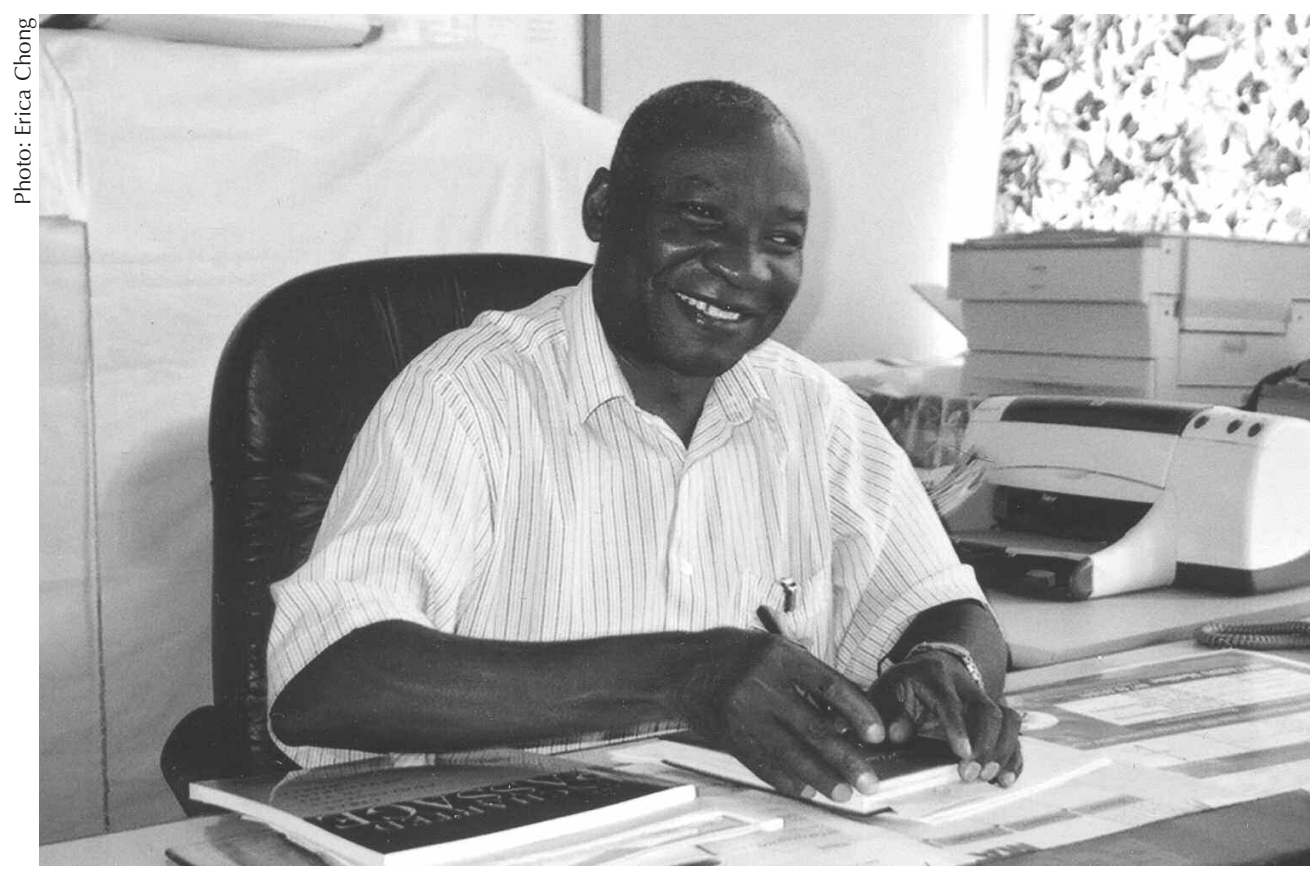

During his medical training, Dr. Balthazar Gumodoka saw the devastating effects of obstetric fistula. He developed a keen interest in helping these patients, but was limited by inadequate facilities and training. Today, he directs the Fistula Project at the Bugando Medical Centre. 
repairs again. He operated on about 20 patients a year, but because he was unable to update his skills and because the hospital lacked a training program for the nursing staff, his effort resulted in a failure rate of about 50 percent.

While Dr. Gumodoka was experiencing this frustration, an American health professional from a very different background was becoming interested in the problem. Maggie Bangser was working in Asia for the International Women's Health Coalition when she first heard about fistula from a colleague who was funding fistula-repair programs in Nigeria. Maggie moved to East Africa in 1992 to head the reproductive health portfolio for the Ford Foundation. She sought to establish contacts with people working on the fistula problem, but found little interest in the issue. In 1995, she relocated to Mwanza to work with a local nongovernmental organization (NGO), where she and Dr. Gumodoka crossed paths. In the course of their conversation, she asked him, "Is anything happening on fistula at Bugando?" and his eyes lit up. They sat down together that day and started working out the details of a comprehensive fistula-treatment program.

The more I learned about the impact of fistula on girls' and women's lives, the more I felt that this was a seriously neglected issue, both from a health and a human rights perspective. Fistula is a microcosm of so many important issues about the lives of women living in poverty and the lives of marginalized women. I realized that it was critical to work on fistula, but it was also critical to address the complex set of issues that result in fistula, and to bring that perspective to bear on fistula work.

- Maggie Bangser, founding member of the Fistula Project at the Bugando Medical Centre

\section{Laying the Foundation}

The first step in developing the program was to create a steering committee, comprised of four other professionals who were committed to helping girls and women with fistula and who were willing to take on extra duties during their already full working days. Besides Maggie Bangser, the other members on the committee were all Bugando-based providers, doctors and nurses from the ob/gyn, anesthesia, and surgery departments. This emphasis on procedure was intentional, because the committee members felt strongly that public education and advocacy should not take precedence over service delivery. Maggie recalled, "We felt it was unethical to raise women's awareness and expectations of treatment if repair services were not in place." During the planning phase, the committee members met about once a month, charted the activities that they needed to accomplish, and divided up specific tasks. Several of the committee members report that a personal experience with a distraught fistula patient motivated them to help build a fistula-treatment project.

When Maggie left Mwanza to form a nongovernmental organization that could carry out national and international advocacy and research on fistula (see Beyond Bugando: A National Partnership on page 25), she was replaced by Liz Mach, a Maryknoll lay missionary and nurse specializing in maternal and child health who had been working in Africa since 1976; Liz continues to serve as the project advisor on the committee. Four of the six original members are still on the project committee, contributing a high level of continuity and stability to the project.

Although he is not a member of the steering committee, the hospital director, Dr. Zachary Berege, was an important ally in this formative stage. In his 


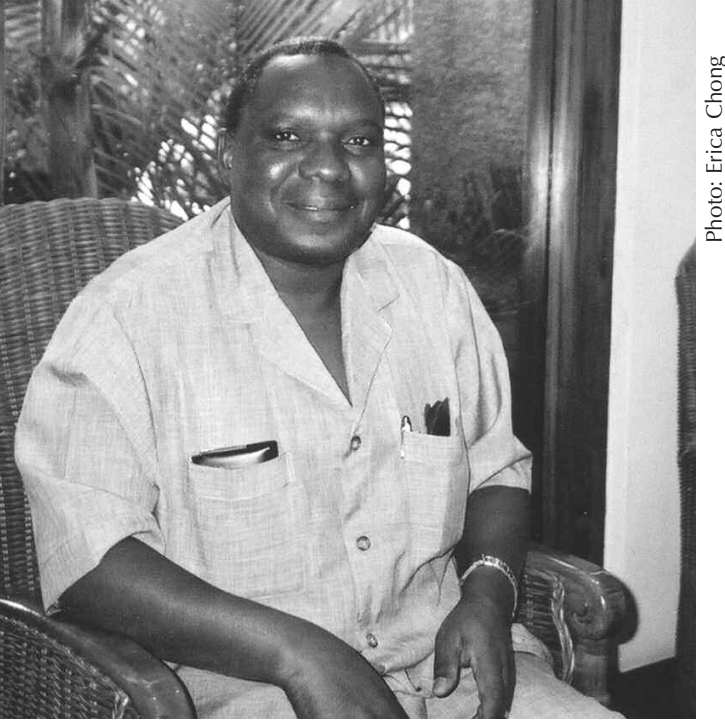

Dr. Zachary Berege, Director of Hospital Services in the Ministry of Health, has been a strong supporter of fistula services.

practice as an obstetrician-gynecologist, he had witnessed at close range the devastation fistula causes. Dr. Berege lent his support to the new project and allocated hospital beds for a fistula ward. When he became Director of Hospital Services in the Ministry of Health, his experience and commitment to this issue helped assure ongoing governmental support.

One of the first activities the committee undertook was to set out the project's objectives. They are: (1) to offer high-quality services and care to fistula patients who come to the Bugando Centre for treatment; (2) to increase community awareness of fistula and of ways to prevent it by means of information, education, and communication campaigns; (3) to increase the hospital's capacity to treat fistula by training nurses and surgeons; and (4) to collect and analyze data in order to better understand the causes and consequences of fistula.

Given that the majority of Tanzanians live on less than $\$ 2$ a day, arranging to have an operation that costs \$250-300 at a hospital that may be more than 500 $\mathrm{km}$ away is simply an impossibility for nearly all the girls and women who develop fistula. The committee members agreed, therefore, that offering fistula services free of charge was of pri- mary importance, especially since the poor are disproportionately affected by this condition.

A current debate among those involved in treating fistula is whether treatment is better accomplished at a freestanding, separate facility committed to the care of fistula patients or in the wards of an existing hospital. Proponents of the former option have seen the stigmatization that can occur when fistula patients are mixed in with other patients and how this disenfranchised group often is bumped to the end of the treatment line. The project committee members were sensitive to these arguments, but felt it was important to provide treatment in the wards so that everyone could see that fistula patients are no different from other patients, and that fistula is the same as any other medical condition for which people

\section{Surgical repair of fistula costs about \$250, but most of the women in need of treatment live on less than \$2 a day. The project committee decided, therefore, that repair services should be offered at no charge.}

seek treatment at a hospital. The committee tried to create the best of both worlds by dedicating a ward in the ob/gyn wing to fistula patients, so that, in Liz Mach's words, "they form a fistula community within the hospital, but they are also part of the larger Bugando community." Shared overhead costs of electricity, water, and staff were also significant considerations in deciding to house the Fistula Project at Bugando.

About eight months after Dr. Gumodoka and Maggie Bangser first met, the project plan was in place; Dr. Gumo- 
doka served as Project Director and Maggie as Project Advisor. Eight months thereafter funding was secured, and by August 1997, the team was ready to begin training and to establish services.

\section{Building Capacity}

The first step of the project was to train the medical staff, starting with fistularepair procedures. In August, three doctors and nurses from the Addis Ababa Fistula Hospital (AAFH) (see box) traveled from Ethiopia to Tanzania to conduct a three-week clinic with 55 medical professionals from Bugando and other Lake Zone hospitals. The Ethiopian specialists shared their expertise in screening, surgical repair, operatingtheater procedures, pre- and postoperation nursing, case management, development of treatment protocols, proper use of instruments and solutions, and patient counseling at discharge. Participants had the opportunity to observe 38 fistula repairs over the course of those three weeks. Of the 38 women treated, all but three were cured. The 92 percent success rate was especially thrilling to those (like Dr. Gumodoka) who had tried for years to help fistula patients but had lacked the necessary equipment, knowledge of modern techniques, and adequate nursing care.

After this initial exposure, Dr. Gumodoka and a senior ob/gyn nurse in turn went to Ethiopia to train intensively for four weeks at AAFH. Further energized, they returned to Bugando and held workshops with their colleagues in the ob/gyn, anesthesia, and surgical departments to share what they had learned. Based on these workshops, the Bugando project adapted the AAFH protocols for their setting and clientele. For example, they introduced new systems of case management and record keeping, upgraded the protocols for cleaning beds and catheters, and strengthened counseling capacity. Financial management systems established by the project committee included a transparent accounting system, as well as local currency and external foreign exchange accounts, a petty cash fund, and a fund for patients' basic needs. With the grant money they had raised, they bought a complete set of surgical instruments for fistula procedures, three beds, and ten mattresses.

\section{The Addis Ababa Fistula Hospital in Ethiopia}

Drs. Reginald and Catherine Hamlin, both obstetrician-gynecologists, left Australia in 1959 to work in Ethiopia. Recognizing the widespread unmet need for fistula repairs, they established the Addis Ababa Fistula Hospital (AAFH) in 1974. Since that time, AAFH has grown into one of the major surgical and teaching institutions in subSaharan Africa. The hospital has provided treatment to more than 20,000 girls and women to date, free of charge and given patients rehabilitation, food, clothes, and money for transport home.

The hospital has made provider training a priority. Ethiopian obstetrician-gynecologists with no previous fistula-repair experience spend two months at AAFH as part of their postgraduate training; surgeons from developing countries and ob/gyns who have already had some experience train for one month. AAFH recently built and opened Desta Mender ("Village of Joy"), a village close to the hospital that can house as many as 100 girls and women who are undergoing physical therapy or whose operations were unsuccessful. Women in the latter category have urostomy bags that require ongoing medical attention that is unavailable in their remote rural villages. At Desta Mender, the girls farm the land, learn how to knit, and spin silk. 


\section{How the Service Functions}

\section{Intake}

Staff are keenly aware that the women who arrive at the hospital are likely to be physically and emotionally stressed. Often they have been traveling for days or weeks; although Bugando primarily

\section{Some women spend years}

negotiating permission to seek

care and saving funds for the

journey. Even then, travel is an

ordeal for a woman who is leaking

urine. Bus or train conductors may

kick her off is she smells too bad

or if other passengers complain. serves the Lake Zone region, patients commonly arrive from other areas as well, even from other countries nearby. (Recently, two women arrived after an arduous 15-day journey from an area near Lake Tanganyika that involved traveling by dhow and train.)

The trip can be stressful for several reasons: Girls from rural areas may never before have left their villages, much less traveled to a bustling port city of several hundred thousand people. Traveling is also an ordeal for someone who is leaking urine. Conductors reluctantly allow fistula patients to travel on buses and trains; They may kick the patients off if they smell too bad or if other passengers complain. Some women have spent months or years negotiating permission to seek care and saving up funds for the journey and the surgery.

About two years after she developed the fistula, Bahati decided to go back to the hospital where she had delivered to see if anything could be done for her. She stayed on the ward for a week and a half before the doctor referred her to the Bugando Centre. Having never been out of her village, she was afraid to travel so far by herself. Her doctor told her not to worry, and found an escort. He paid for her and for a nurse to make the 13-hour bus trip to Mwanza. Upon arriving at Bugando, Bahati was shocked to see so many girls with fistula. She had never heard of the condition and had assumed that she was the only one with this problem. She felt emboldened to see that she was not alone and was anxious and excited as her surgery date approached. Before the operation could proceed, Bahati had to be treated for anemia and for a vaginal infection.

\section{Integrating Fistula Patients into the Hospital Community}

The overriding philosophy of the Fistula Project is a departure from typical hospital care in that the girls' and women's social as well as medical needs are placed front and center. As Liz Mach, the current project advisor, notes, "After the ordeal that these women have been through, the stigmatization and abandonment, we really want them to feel welcome here. This is a safe haven for them, and they know that they can come here and be treated with dignity." At the beginning of the project, people asked the staff why they were putting sheets on the beds of fistula patients when they would only be soiled the next day. A ward nurse explained, "It doesn't matter if the sheets are a mess; we'll wash them. Putting sheets on their beds is about normalizing the situation, giving these patients some dignity back."

Nurses perform double duty in helping these girls and women begin the 


\section{Gathering Hope and Determination}

Whether they come from near or far, these girls and women are usually malnourished, their only belongings being the clothing on their backs. Moreover, because they typically drink as little as possible to limit the amount of fluid they leak, many experience chronic dehydration, which can lead to kidney stones. One woman had a stone in her bladder the size of a golf ball. Dehydration also concentrates the ammonia in urine, often causing dermatitis or excoriation of the vulva. One of the first tasks at intake is medical triage, so that staff can determine whether a patient has a fistula or severe stress incontinence and whether she has any conditions or infections that must be treated before she can undergo surgery. If the fistula developed recently (within a week or so), the staff may first attempt to treat the tear nonsurgically (by inserting an indwelling catheter for four to six weeks and ensuring adequate hydration). Approximately 10 percent of cases can be healed in this manner.

After living with fistula for nine years, Ndebele heard an announcement on the radio that a cure was available for her condition. This new information gave her hope, but it took two years for her to scrape enough money together to visit a hospital. The family's resources were particularly low after her mother's sickness and death in 2000. Last year, Ndebele's uncle took her to a nearby town where they stayed for five months while he tried to borrow money for her trip from his contacts there. Their efforts were cut short and the family set back again when her sister died. Eventually Ndebele saved up some money from selling beans and ground nuts and borrowed money from her relatives to pay for transportation to the closest hospital where doctors catheterized her for 14 days. Her fistula hole did not close, however. While in the ward at the hospital, Ndebele heard about the Fistula Project at Bugando and the free treatment available there. After struggling for so long to reach the first hospital, she had no idea how she would travel to Mwanza. A sympathetic nurse noticed her distress, and upon hearing her plight, went to the hospital administrators and arranged transportation funds for her.

One year after she developed a fistula, Mwasiti decided to seek help. She traveled to the mission hospital in Bunda, where the doctors attempted to repair the hole. The surgery failed, and Mwasiti was more despondent than ever. In the years that passed, Mwasiti's sister was unflagging in her support, telling Mwasiti not to worry, that she would be cured, that everything would turn out fine. One day, they heard a radio presentation that described fistula and mentioned that Bugando Medical Centre was repairing patients at no cost. Mwasiti was scared to try again; she didn't think she could be treated because the first attempt had failed, and she did not want to experience such severe disappointment again. Her sister encouraged her to try, and soon after, the two of them traveled to Mwanza.

After hearing an announcement on the radio that Bugando was treating women with fistula, Rhobi's doctor drove her for more than two hours on the bumpy and pot-holed dirt roads that led to Mwanza. Rhobi arrived at Bugando leaning on a stick to help her walk, with nothing more than a sheet wrapped around her and a piece of plastic to sit on. She had scabies and a chest infection, and was afraid to be so far from home. When the nurses explained the surgical procedure to her, she was frightened of the spinal needle required to administer the anesthesia, and she almost called off the operation. The staff spent hours calming her down and were finally able to convince her by praying together and asking her to have faith that God would take care of her.

Hidaya, a 42-year-old woman, had lived with a fistula since she was 19. After spending four days in labor, her child was stillborn and she was leaking urine. Her husband had left her after she developed the fistula. Two previous repair attempts in 1980 and 1988, failed. In 2001, a health worker told Hidaya about the fistula project and suggested she try again. Upon admission to Bugando, she was examined and found to have six fistulae. The surgeon who operated on her was not optimistic about her chances. 


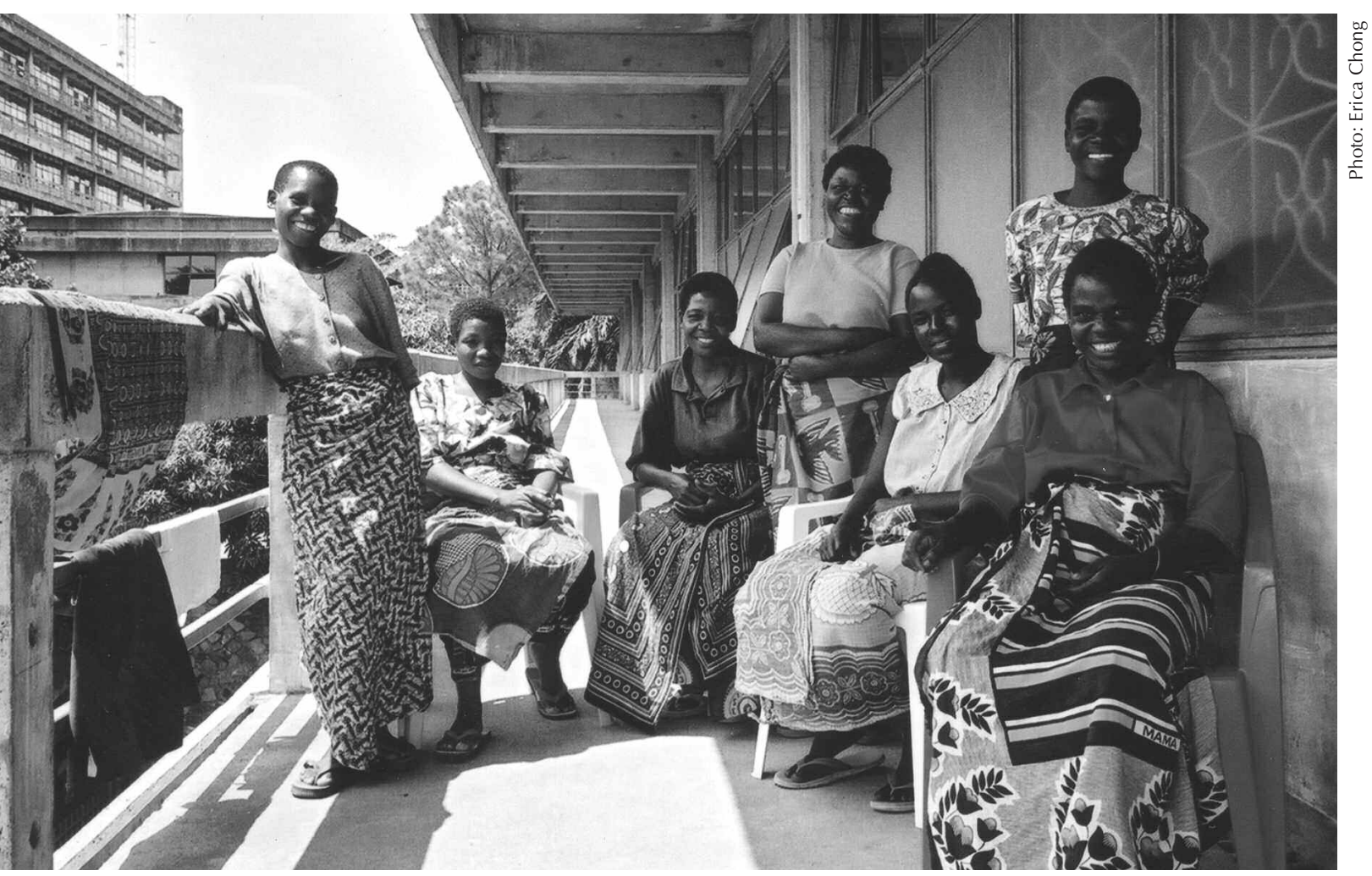

The fistula ward is a safe haven for the patients there. For many, this may be the first time since developing a fistula that they have found acceptance and been treated with dignity; the opportunity to commiserate over the loss of a child or the abandonment by a husband provides critical support.

healing process by acting as counselors. They are keenly aware that these patients may be experiencing multiple losses - of child, husband, reproductive ability, livelihood, self-esteem, and social status-and that they need time to grieve and talk. At the same time, the nurses also guide the fistula patients to start thinking about their time at Bugando and about their futures. They help patients clarify their needs, concerns, hopes, and expectations. Some patients (particularly the younger ones) become so attached to the nurses that the nurses function as their surrogate mothers or older sisters. In a further effort to humanize care and reduce fear, the anesthesiologist routinely meets with each woman before her surgery so that she will see a familiar face in the operating room.
Perhaps one of the most powerful aspects of the patients' experience at Bugando is the time spent with the other girls and women on the fistula ward. Most of the patients are shocked to discover that they are not alone in experiencing this condition. Those who arrive sad and anxious because they have little hope that they can be healed are reassured to see other women in rehabilitation after surgery. For many, this may be the first time since developing a fistula that they have found acceptance; the opportunity to commiserate over the loss of a child or a husband's abandonment provides critical support. One patient, Furaha, commented, "It is great to be with other girls who understand what I'm going through. We tell each other about our problems and about how things were after we devel- 
oped the fistula." Another patient reacted with anger, saying "When I saw all the fistula patients on the ward, I realized that this is a big problem. Why did no one ever tell us about this before? If I had known about fistula, maybe I could have prevented it, or at least I would have come here sooner."

Depending on several factors-the need for physical therapy, treatment for infections and other diseases before surgery, patient load, and failed surgeries-patients may remain on the ward for a few weeks to several months. During this time, if the nurses or volunteers are available, the girls and women may learn Swahili, knitting, crocheting, or literacy skills. Liz Mach notes, "Not only do such projects give them something to look forward to and something to keep their minds off their problems, but these are useful skills to return home with, and the patients bond as they teach each other." Crocheting is an activity that can be performed while sitting, an important consideration for those who may experience stress incontinence or who are still leaking after surgery. A request for supplies included in the fall 2000 issue of Vogue Knitting International received an overwhelming response: AmeriCares shipped thousands of pounds of yarn and knitting needles to Bugando from supportive readers. Knitting also provides another avenue for the patients on the fistula ward to feel connected to the larger Bugando Medical Centre community, because many of the blankets, sweaters, and baby booties they make are donated to other patients who need them.

\section{Surgery and Postoperative Care}

Given the great demand for fistula repairs, the project faces a constant challenge in ensuring adequate surgical staffing. Dr. Gumodoka performs both simple and complex repairs, but his time is limited by his administrative duties as Deputy Director of the hospital, Head of the Obstetrics/Gynecology Department, and Director of the Fistula Project. Therefore, the project still relies heavily on the visiting surgeons for about half of all repairs. Dr. Kelly continues to spend six weeks each year at Bugando, repairing about 120 fistulae; Dr. Raassen performs about 20 repairs during two one-week stays at the hospital.

In the meantime, the project is slowly building local expertise. Two Tanzanian surgeons, Dr. Marietta Mahendeka and Dr. Nhandi Ng'walida, have both com-

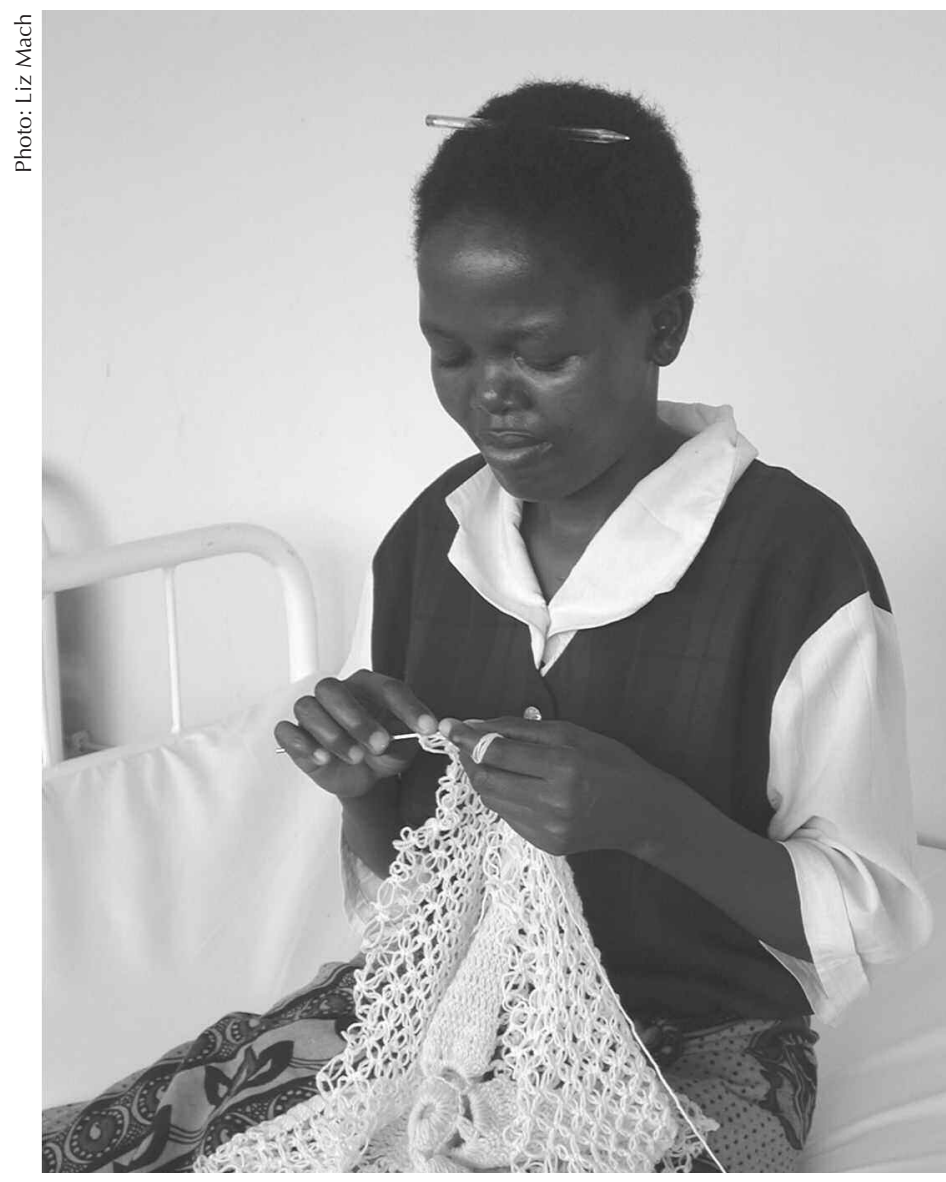

Patients may remain on the ward for a few weeks to several months. Many learn Swahili, crocheting, or literacy skills, activities that can be performed while sitting. After placing a request for supplies in Vogue Knitting International magazine, the project received thousands of pounds of donated yarn and needles. 


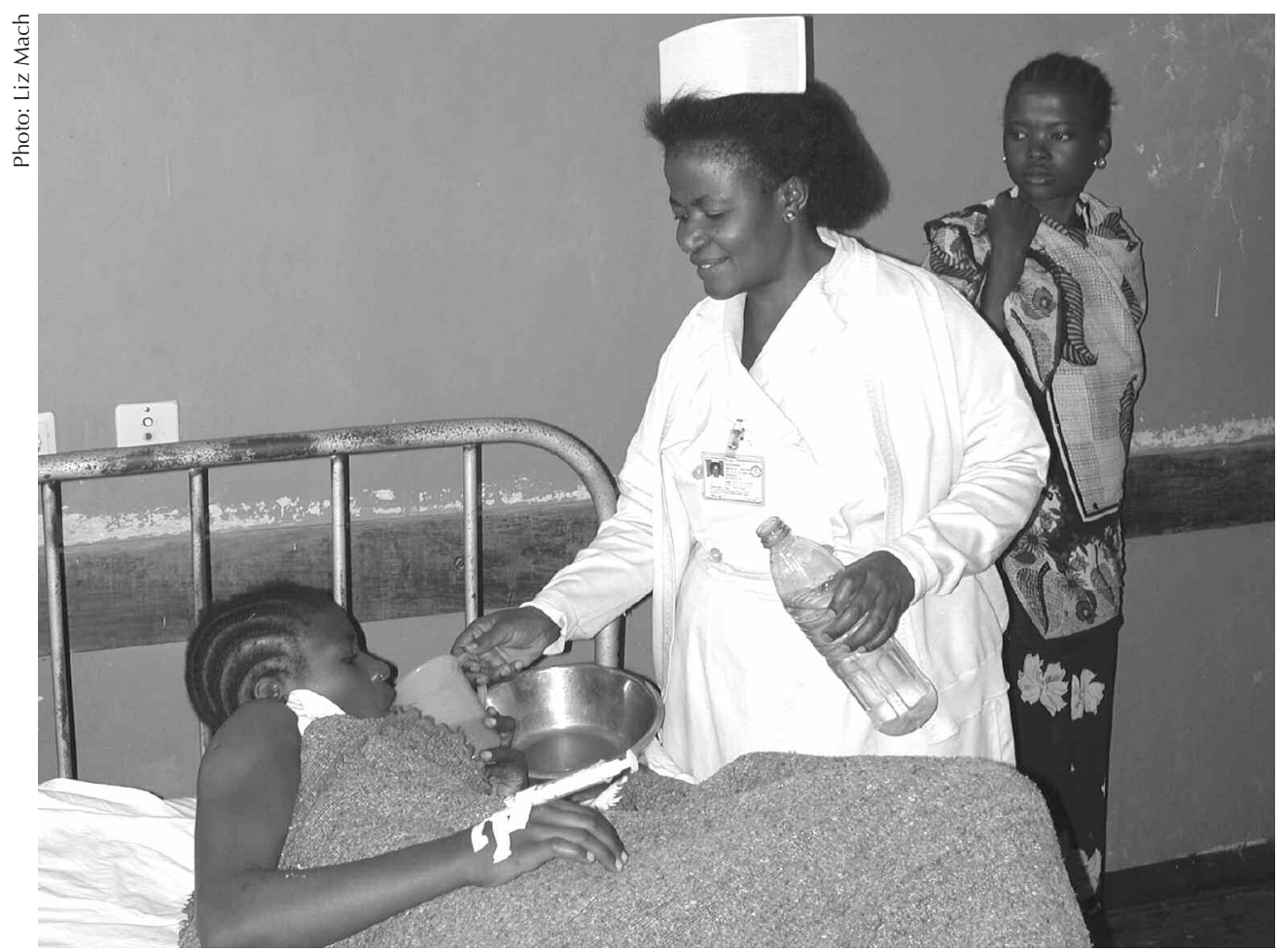

After the operation, the patient rests in bed for two to $\mathbf{1 4}$ days. Good postsurgical nursing care is essential to successful outcomes.

After the operation, the patient rests in bed for two to 14 days. (The protocol varies according to the surgeon; the postsurgical hospital stay is an issue of ongoing discussion and study.) Although the surgery is obviously of critical importance, good nursing care is essential, especially in the postoperative period. Often, without proper postoperative care, the repair may break down. Because the patient is still using a urinary catheter and has a contracted bladder (her bladder has not been used for storage of urine since the fistula occurred), any stretching of the bladder by retained urine may cause the fistula to reopen. Along with providing good wound care, nurses must monitor catheter drainage to ensure that no blockage occurs, and they must supply patients with large amounts of fluids and appropriate nutrition during their rehabilitation.
After surgery, some patients continue to experience stress incontinence, for example, leaking urine in response to sneezing or lifting heavy objects or from a full bladder after a night's sleep. Nurses find that teaching fistula patients to perform pelvic-floor exercises enables many of them to regain sphincter control. Liz Mach recalled exit interviews with several patients, one of whom, when asked if she was dry, replied, "I have stress incontinence. But I'm doing my exercises right now, are you?" Liz was delighted that the patient felt calm about having some stress incontinence because she felt as if she had control over it." Understandably, the patients are elated when a surgery is successful and they no longer leak urine or feces. During another exit interview, when the patient was asked if she was dry, she jumped to her feet, lifted up her skirt, and said, "Look! I'm wearing underwear for the first time in years!" 


\section{Surgical Outcomes}

The Bugando Fistula Project considers patients healed if they are "dry" (that is, only if they have stopped leaking altogether). Analysis of cure rates based on 645 repairs shows that 74 percent were healed, 5 percent failed, and 20 percent were partially successful (the women still had some degree of stress incontinence). Stress incontinence can range from a mild condition to leaking as badly as if the woman still had a fistula. Although some cases of stress incontinence can be improved with pelvicfloor exercises, others may require further surgery, and a few are incurable. Some cases are more difficult because a woman has already undergone an unsuccessful attempt at repair, often at a smaller, poorly equipped hospital. Because the affected area is relatively small, and because scar tissue builds up with each operation, the first surgery provides the best opportunity to repair a tear. Liz explains, "Early on, we were seeing a lot of patients who had had repairs performed at other places, repairs that had failed, which made it harder to cure them." Sometimes pinpointing precisely the reason an opera-

When the patient was asked if she was dry, she jumped to her feet, lifted up her skirt, and said, “Look! I'm wearing underwear for the first time in years!"

tion fails is difficult. Perhaps the tear was very large, or the tissue was heavily scarred, or the patient's immune system was compromized by HIV. The staff provide these patients with extra care and counseling and assure them that they will try to help them again and will not abandon them.

\section{What about Ndebele, Mwasiti, Bahati, and Hidaya?}

Ndebele's surgery was unsuccessful, but she remains hopeful that the second attempt will finally put an end to the years of discomfort and embarrassment.

Mwasiti's bed, contrary to her expectations, was dry 14 days after her operation.

Surgery also successfully closed Bahati's fistula, but she is having moderate stress incontinence.

And 42-year-old Hidaya? After a successful repair and a dry bed, hospital staff had to force her to leave because she was going up and down the hallways singing, dancing, and creating a ruckus.

\section{Going Home}

Every patient undergoes an exit interview. One purpose of this interview is for the staff to supplement basic statistical information gathered from the patient upon admission-mostly about such social, economic, and health indicators as age at marriage, age at first pregnancy, parity, educational attainment, care received during pregnancy and labor, details of her fistula, and current living situation. More importantly, the exit interview provides an opportunity for a closing counseling session to teach the patient how to take care of herself and encourage her to think about what life will be like when she goes home. Some patients never stopped menstruating; others will have their menses return after repair, and they may be able to have children. The girls receive contraceptive counseling, and are advised to abstain from sex for six months (by suggesting six months, the counselor is hoping for three months). They are told that if they become preg- 
nant, they should obtain antenatal care, deliver in a hospital, and be sure to tell the doctors that they have had a fistula. They are also advised that they may need a cesarean section. The nurses try to ensure that the patient has a plan in place: Where will she live? How will she support herself? Does she want to marry again or, if her husband is still around, how does she think he will respond to her return?

\section{Fourteen days after her surgery, Rhobi} was dry and ready to go home. Because she had been brought in a vehicle by her local doctor and had never left her village before, Rhobi had no idea where her home was or how to get there. Several staff decided to retrace her steps. Rhobi could remember the general direction of the health center that referred her to the hospital. The center's staff, in turn, directed Rhobi and the staff toward her village. Although they drove through the village twice, Rhobi had never seen her village from a car and nothing looked familiar. Finally she recognized a man on the road who got into the car and led them to her grandmother's house, where she had been living. As Rhobi stepped out of the car, the villagers flocked around, and her grandmother came out of the hut with tears streaming down her face, saying "They told me you were dead!"

Other patients have little to go home to. In a few cases, these patients have worked as ward attendants on the fistula unit until they acquire some savings to start them off when they leave for home. Such attendants have provided a useful bridge between patients and hospital staff and are key resource people. Programs in other countries use similar strategies. One extraordinary case is the fistula patient who was treated at AAFH when she was a teenager. Unable to return home, she assisted with fistula surgeries under Dr. Reginald Hamlin's guidance. Demonstrating an aptitude for the work, she eventually became a surgeon herself; to date, she has performed thousands of operations, and is one of the hospital's best trainers.

Little is known about fistula patients' reintegration into their communities after surgery. The Bugando Project now plans to follow up girls and women who have returned home to learn about their individual experiences and whether they are accepted back into their communities and back into their marriages. Do they return to the same situation of overwhelming poverty and gender inequity that created the conditions for fistula in the first place? Are they able to become pregnant again, if that is their goal? How do subsequent deliveries go? What requirements do women have upon reintegration that the program should consider more carefully? Is

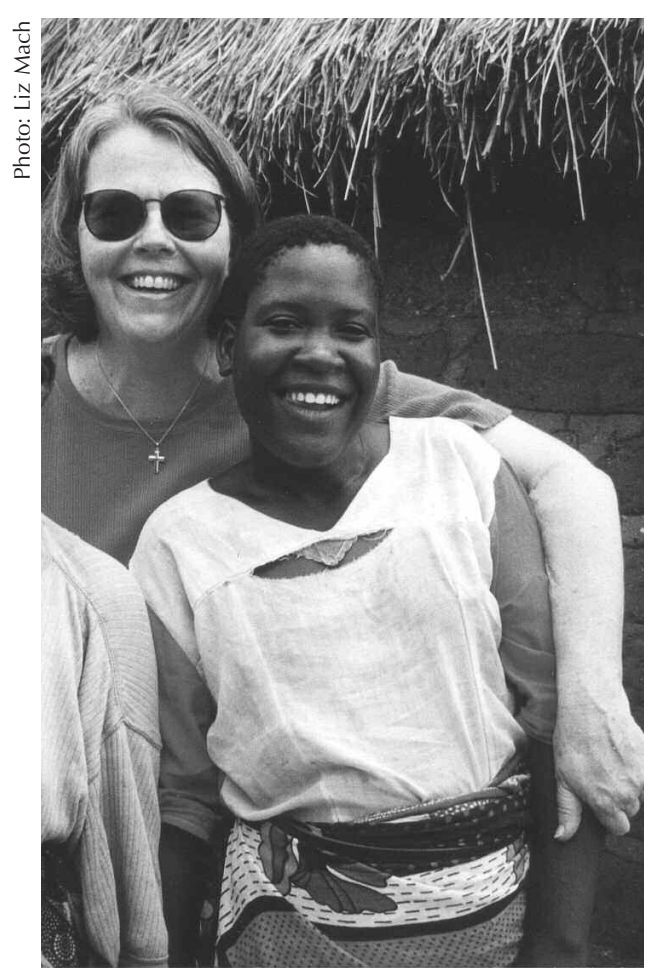

Above, Liz Mach with a patient who has returned home. 
there a greater demand for livelihoodskills training? The staff are considering how they would deal with the challenge of locating former patients throughout the country and how the interviews could be conducted most effectively in order to yield useful lessons.

\section{Team Management}

The project staff have full team meetings with doctors, anesthesiologists, and operating-room and administrative staff two or three times a year. These meetings usually last a few hours and are used to orient new team members, discuss outstanding issues, and prepare for or evaluate a visiting doctor's stay. Regardless of his or her placement in the hospital hierarchy, every member is encouraged to contribute ideas for making the unit more efficient and to raise concerns. Several team members mentioned that these meetings were important for boosting morale and providing encouragement, and that the open nature of the meetings led to a sense of personal ownership of the project.

\section{Challenges}

As of 2001, approximately 50 hospitals in Tanzania were providing fistula repairs; six of these hospitals, however, were performing the majority of all repairs. The Bugando Medical Centre handled approximately one-fourth of cases nationally, the highest share of any hospital (WDP 2002). The number of fistula surgeries has increased from fewer than 30 a year (before the collaborative fistula project began) to 228 patients in 2002, an increase accompanied by a greatly improved success rate. The quick growth of the project prompted the committee to request additional space in Bugando. In 2002, Dr. Charles Majinge, a surgeon trained in fistula repair who had succeeded Dr. Berege as hospital director, granted the project the use of an additional 50-bed ward, expanding the number of Fistula Project beds to 95. This new ward serves as a holding area for patients before surgery and as a recovery room when the main ward is full.

Expanding capacity allows the project to serve more women, but has

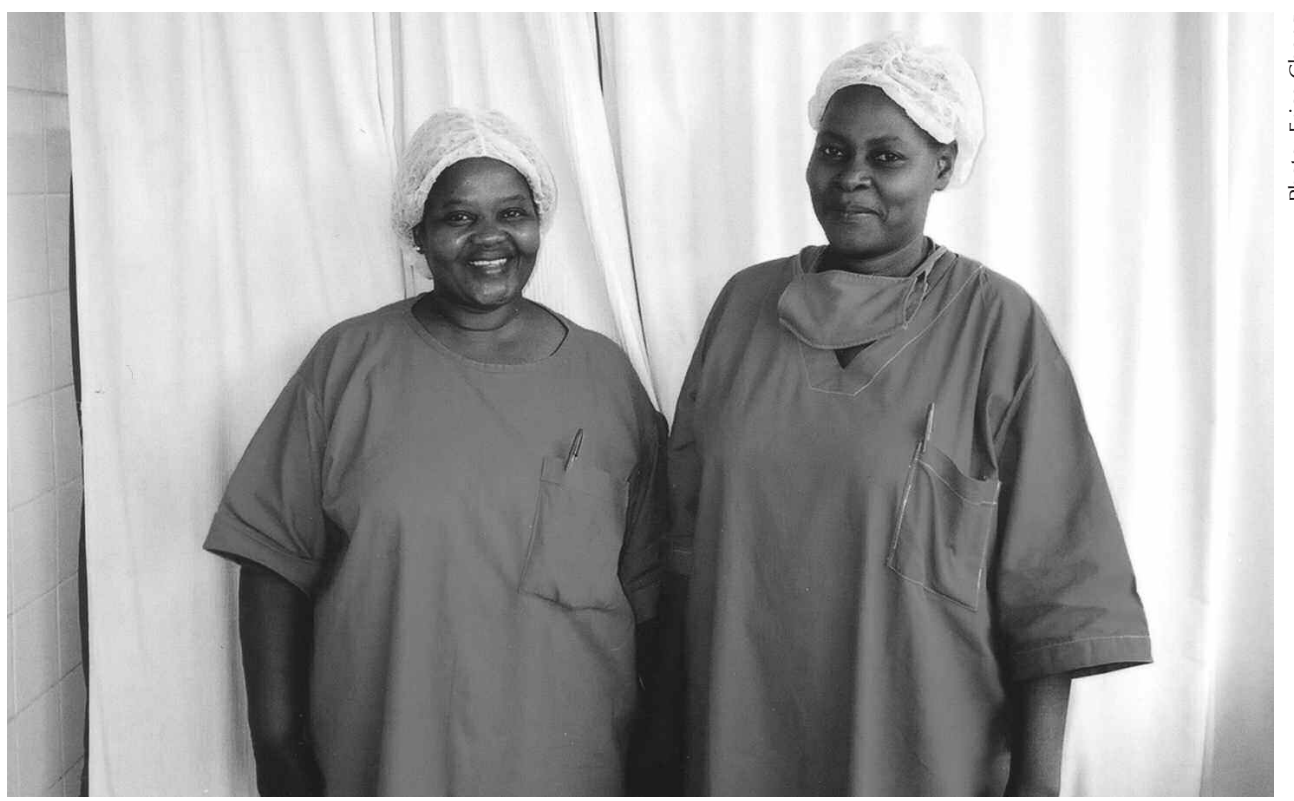

Working on the fistula ward is difficult and is a voluntary assignment. Nevertheless, the project attracts dedicated nurses, and turnover is low. 
exacerbated several preexisting problems. Most of these difficulties involve staffing and meeting expenses.

\section{Raising Program Funds}

The Fistula Project staff estimate that providing the surgery and covering the cost of lab tests, medication, food, staff wages, and transportation for the patient's trip home costs about $\$ 250$ per patient. Liz Mach has been instrumental in keeping the project afloat through her fundraising efforts. The project's funding has come from four main sourcesMaryknoll (the US-based Catholic mission movement to which Liz belongs), the Oak Foundation, the Women's Dignity Project, and donations from Liz's own family and friends. In addition, the African Medical and Research Foundation contributes $\$ 100$ (funding from the Royal Netherlands Embassy) for each patient who is treated by visiting AMREF specialists. The Bugando Medical Centre provides use of the physical plant (electricity, water, use of wards, and so forth) but does not contribute toward the costs of treatment for fistula patients. Liz maintains that no patient has ever been turned away because of lack of funds, but the scramble to cover costs is constant, and budget limitations have hampered some of the project's research and outreach goals.

\section{Strengthening Local Capacity}

Given the severe shortage of doctors in Tanzania, the number of obstetricians/ gynecologists or surgeons with expertise in repairing fistula is woefully small. Visiting doctors provide a sorely needed service. Dr. Kelly still performs nearly 50 percent of Bugando's yearly caseload of fistula patients, and Dr. Raassen handles almost 10 percent. The in-house staff often assist in difficult surgeries, so

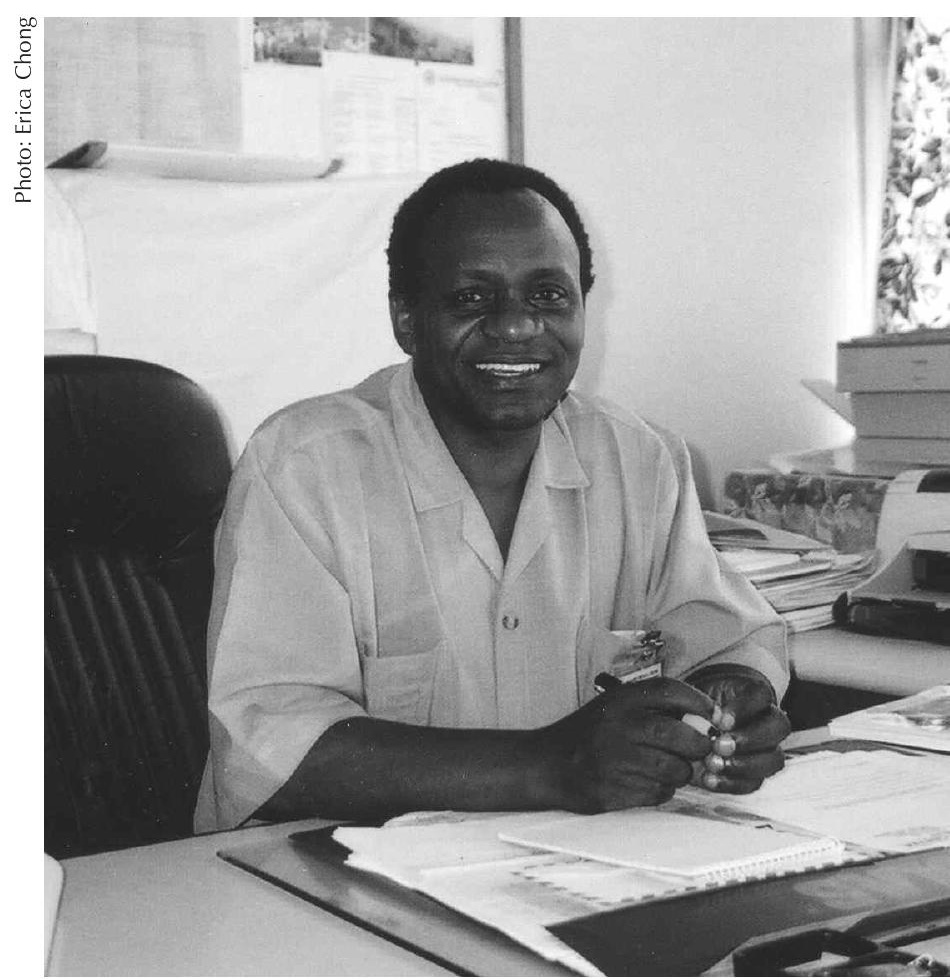

As the number of fistula patients grew, hospital director Dr. Charles Majinge (a surgeon with experience repairing fistulae) increased the number of beds available on the fistula ward from 50 to 95 .

that they continue to develop expertise as they seek to optimize the chances for their patients' complete recovery.

Reliance on visiting surgeons, however, places a strain on the system. Because the Tanzanian surgeons often refer the most complicated cases to a visiting surgeon, the project houses some patients for up to several months in the interim. Moreover, to make the most of the outside surgeons' visits, staff must mobilize for several weeks in advance. They arrange for radio announcements and send e-mails to refugee camps and district hospitals. The operating-room staff, anesthesiologists, and ward nurses review their checklists and submit their orders for medication, sutures, catheters, and other supplies to ensure that everything necessary is available and prepared. 


\section{Creating Incentives to Prioritize Fistula Care}

The Tanzanian staff do not work with fistula patients primarily for financial gain; indeed, government salaries are so low that many hospital staff members hold a second job in the private sector. Because fistula patients generally are poor and require lengthy operations, repairs typically generate low fees. These low financial incentives led to two serious problems at Bugando: First, the project encountered difficulty enlisting and retaining staff, particularly doctors. Second, the surgeons often bumped fistula patients from their place in the surgical queue in favor of procedures that were more urgent or that generated more income. The project decided to remedy the situation by scheduling fistula patients for surgery after normal working hours and compensating staff for overtime work, at a rate of about $\$ 12$ a day for doctors and $\$ 8$ for nurses.

The policy of paying the clinical staff who perform fistula repairs additional monies initially caused some tensions within the hospital. Staff in other departments wondered what made fistula patients so special that their care merited extra pay. Everyone involved in caring for fistula patients from kitchen staff to the pharmacists asked why they didn't receive extra money as well, even if they were not working overtime. Liz Mach believes that the overtime pay has allowed the project to develop a stable clinical team and that, along with strict hospital regulations, it has contributed to a decline in corruption and bribery, which are ongoing concerns in settings where people are struggling to meet their daily needs. To address the problem of retaining doctors in the face of a national trend, Dr. Majinge opted to allow all staff physicians to see private patients at the hospital. As a result, many more staff now have supplemental earnings, and this strategy has quelled some of the discord concerning the project.

\section{Maintaining the Quality of Nursing Care}

Because good nursing care is essential to fistula repair, the project strongly emphasizes the development of nursing skills. This effort has been especially challenging in light of the exponential growth in patient load.

Training is important to orient new staff properly (four new staff were added with the opening of the additional ward) and reinforce proper technique. The project committee encourages specialists to visit and conduct hands-on workshops in which the participants watch and then perform nursing procedures. The project committee organizes much inhouse training as well, ranging from an informal approach (training new nurses by having them shadow a more experienced nurse) to a highly structured oneor two-day seminar. A mandatory seminar held in 2001 for all nurses and nursing assistants on the fistula ward was well received. The trainers staged two scenarios in which patients received pre- and postoperative care and asked participants to identify the mistakes that had been purposely inserted into the scenario. Another set of role-playing concentrated on nurses' occasional reticence about approaching visiting doctors to confer about a patient's care or to ask the doctors questions. These activities generated lively discussion (and some hilarity), and served to energize the group and increase its cohesion.

Yasinta Mkama (the head nurse of the fistula ward) keeps a close eye on the nurses on her ward and constantly underscores the environment the project seeks to create for these patients. She reflects, "When some nurses are first assigned to the ward, they treat the girls poorly, and speak badly to them. I say to them, "How would you feel if it were your mother or your sister with fistula, and someone was treating them like that?" or "It could easily be you tomor- 


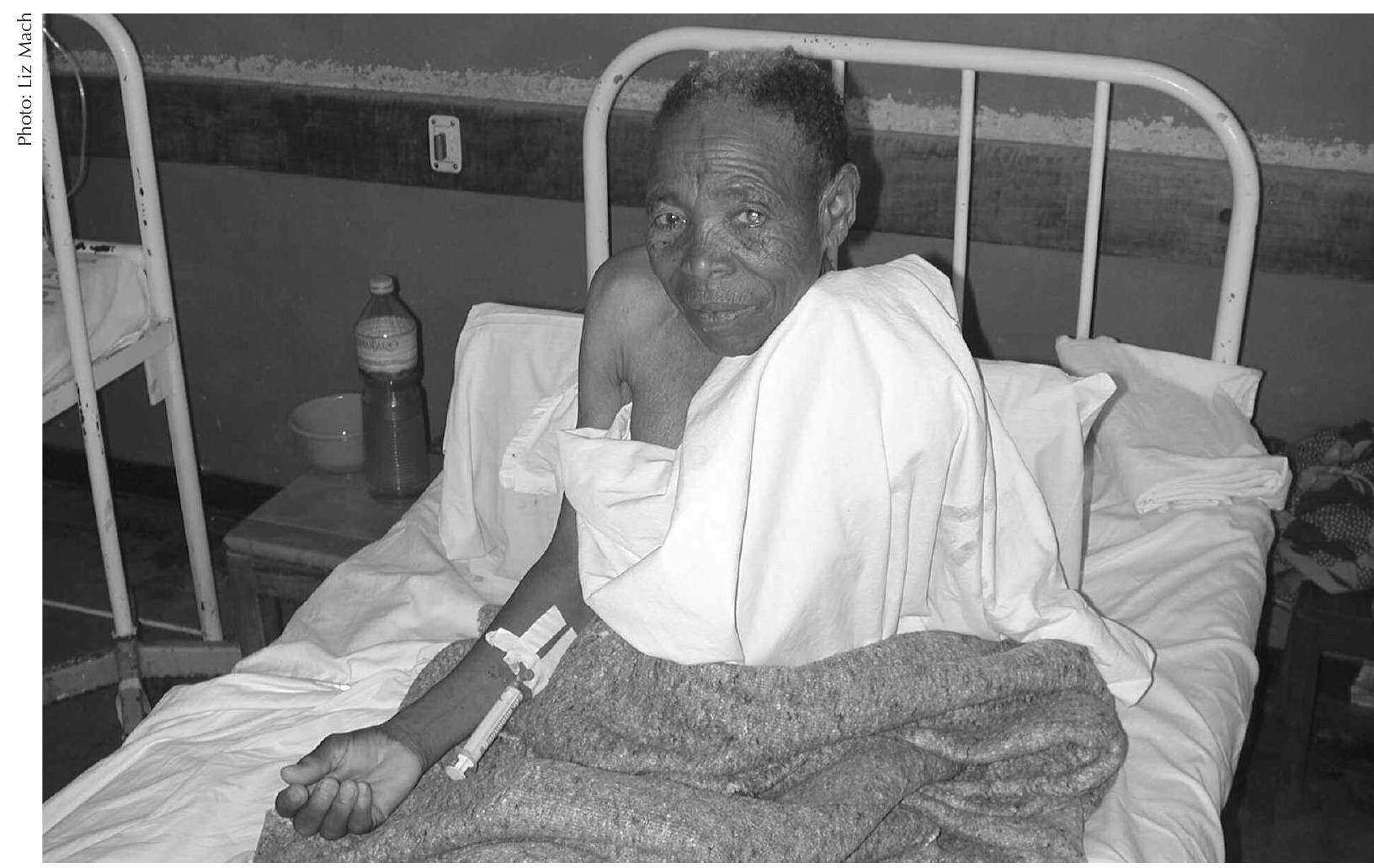

The head nurse at the project tells her staff, "Put yourself in your patients' shoes and imagine how they're feeling."

row who gets fistula. Put yourself in their shoes and imagine how they're feeling." If a nurse feels uncomfortable on the ward, she can request a transfer, but the project staff try hard to work out such difficulties once a nurse has been trained. In the past year, only two nurses have rotated off the fistula ward.

\section{Beyond Bugando: A National Fistula Partnership}

Performing surgical repairs is a critical element of any effort to address obstetric fistula, but a comprehensive approach to this issue must also tackle matters such as raising awareness about the possibility of repair; identifying women in need of surgery; developing strategic plans for managing and facilitating care; mobilizing resources both nationally and internationally; and, especially important, reducing the incidence of fistula through increased access to emergency obstetric care for poor women and girls and promoting the importance of women's health and rights. Tanzania has a remarkably strong network of NGOs, hospitals, government agencies, and international organizations working on these issues; participants in this network share experiences, provide each other with information and advice, supply financial assistance, and relay particularly moving patient stories. In addition to the Bugando providers there are several key actors:

The government has been a principal partner in the national effort to combat fistula. Dr. Zachary Berege, who was so helpful in the formative stages of the Fistula Project as Hospital Director, left 
Bugando in 2000 to serve as Director of Hospital Services in the Ministry of Health. During his tenure at the Ministry, Dr. Berege has been successful in raising awareness of fistula, securing funds in the national budget for fistula care, and making important strides in establishing a national referral system.

The Women's Dignity Project (WDP) was founded by Maggie Bangser in 2000 to focus on fistula in a larger social context, linking health policies and resource allocation as critical underpinnings shaping the health outcomes of poor people. WDP currently has a staff of 15 and focuses on four distinct areas of work: (1) community-based research, analysis, and planning on fistula and social vulnerability, for example, the social and economic determinants that may increase the risk of fistula; (2) organizational capacity building in the areas of fistula treatment and gender and health equity; (3) policy analysis and critique; and (4) resource mobilization for fistula repairs.
The Tanzania Midwives' Association (TAMA) works to educate village leaders, patients, and community members about a range of reproductive and maternal and child health issues, including fistula. It works closely with the Bugando project; indeed, TAMA has one of its branches at Bugando and one of its officers, Esther Mashauri, is an original member of the Bugando Fistula Project Committee.

The ways in which this partnership between the government, the Bugando hospital, and civil society is working to win the battle against obstetric fistula are described below.

\section{Building Demand for Fistula Repair}

A girl or woman with fistula is unlikely to understand what has happened to her or realize that an effective treatment exists. Accordingly, the network of organizations working on fistula has used a wide range of avenues to educate peo-

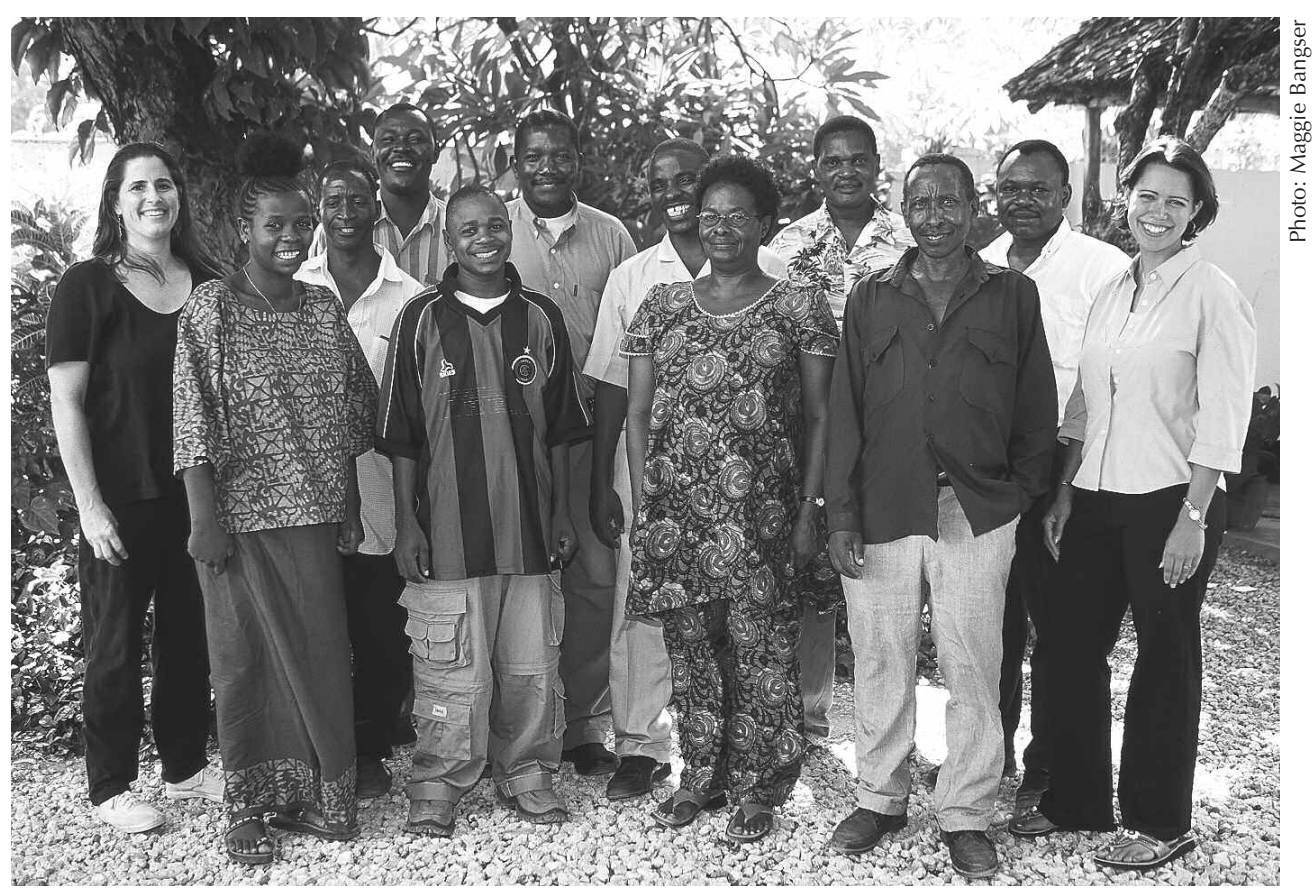

The staff of the Women's Dignity Project 
ple about what fistula is and where one can go to get treatment for the condition. In hospitals, dispensaries, and health centers, members of the Tanzania Midwives' Association in the Lake Zone have shown videos, produced radio announcements, and helped post information sheets about fistula and about the project at Bugando. The Bugando staff also conduct radio interviews in English and in Swahili, and one television network produced a 30minute program on the project.

In early February of 2004, the Women's Dignity Project launched a media blitz about fistula that included their new booklet "Faces of dignity: Seven stories of girls and women with fistula." The Minister of Health, Anna Abdallah, officiated at the launch, where she spoke about the personal dimension of her desire to help women with fistula: Her great-aunt had fistula, and lived out her life with the condition suffering severe hardship and discomfort. "Faces of dignity" and its Swahili version "Sura za utu" were distributed through three major newspapers, whose combined readership is about 60,000 .

The benefits of close collaboration with Tanzania's thriving NGO community are apparent. One NGO working in villages on the problem of female genital mutilation recently identified seven women with fistula (including a 17-year-old girl who was beaten during her prolonged labor to expedite the delivery). The organization contacted the Women's Dignity Project, which arranged for their transport and treatment at a hospital in Dar es Salaam.

The number of women that need fistula repairs is immense, because the backlog of cases is built not on years but on decades of untreated fistulae. In the course of carrying out field research in a few villages, the Women's Dignity Project recently identified 16 women with fistula in only two weeks. Many of these were older women, including two who have lived with a fistula for more than 35 years. One by one, these women joined the researchers in a "caravan" that traveled to Bugando for treatment.

\section{Building National Capacity}

A critical element of the Tanzanian fistula program has been the creation of a

\section{One NGO working in villages on the problem of female genital mutilation recently identified seven women with fistula (including a 17-year-old girl who was beaten during her prolonged labor to expedite the delivery). The organi- zation contacted the Women's Dignity Project, which arranged for their transport and treatment at a hospital in Dar es Salaam.}

national referral system. In 2001, the Ministry of Health and the Women's Dignity Project jointly sent a brief survey to all district, regional, and mission hospitals in mainland Tanzania to inventory which regions and hospitals were providing fistula repairs, and to learn about what barriers existed to women's access to these services. (See box for major findings of the Tanzania Fistula Survey.)

Advocates for the treatment of fistula used the results of the survey to lay the groundwork for the national referral system. Representatives from the Ministry of Health, the Women's Dignity Project, eight hospitals, donor organizations, and other partners came together 


\section{The Tanzania Fistula Survey Results}

Of 172 hospitals surveyed, 138 (80 percent) responded, indicating a high level of interest in the problem of fistula. Major findings included the following:

1. Fifty hospitals performed a total of 712 repairs in the period 2000-01. The number of repairs performed at individual hospitals ranged from one to 172 .

2. The five major hospitals providing repairs are located along the perimeter of the country, so that treatment of the condition remains largely unavailable throughout the interior.

3. Only 12 Tanzanian doctors have received training from a fistula specialist. Therefore, any hospitals that provide fistula care depend on visiting foreign surgeons to perform the operations.

4. The cost of fistula treatment and of transportation to a treatment location are overwhelming barriers for many women. Although many hospitals have some sort of cost-sharing scheme, fistula patients were charged a median fee of $\$ 26$ for repairs. Many fistula patients must travel more than 500 kilometers to reach one of the major repair centers.

5. Nineteen hospitals performing repairs reported that they have inadequate supplies of surgical materials and that their equipment is outdated.

in October 2002 to discuss how a referral system would work and how it could strengthen provision of fistula care. They envisioned a three-tier system in which the first tier would include every hospital providing obstetric care, with providers knowledgeable in prevention, diagnosis, and early treatment of fistula with a catheter. Eight second-tier hospitals in underserved areas and with the potential to expand clinical capacity were identified to perform simple repairs and to screen and refer more difficult cases to third-tier centers. Five third-tier hospitals were selected where resident doctors and nurses could handle large numbers of fistula patients and manage complicated cases. Doctors from either third-tier centers or visiting surgeons would provide the necessary training for doctors at second-tier centers. ${ }^{3}$
Responding to feedback from providers and from women with fistula, the referral system has been modified to train a larger number of doctors at second-tier hospitals. Responding to the numerous obstacles women face in traveling long distances to seek fistula repair, treatment advocates decided to concentrate their efforts on bringing care closer to women with the condition by increasing capacity at more, and more widely distributed, hospitals that can perform simple repairs.

\section{Influencing Resource Allocation}

The network of individuals and organizations working on the problem of fistula are seeking to increase funding for fistula treatment nationally and interna-

\footnotetext{
${ }^{3}$ Currently, Bugando staff travel to remote hospitals under the auspices of AMREF's Specialist Outreach Program. The surgeons perform repairs, lecture, teach local medical staff to assist during the operations, and work to spark surgeons' interests in seeking further training. Elizabeth Bushiri, nursing officer in charge of the Bugando operating room, frequently conducts one-day seminars for surgical nurses and assistants from the surrounding areas.
} 
tionally. In part, they have sought to increase funding directly for surgical repairs. The support and commitment of both the Minister of Health and the Permanent Secretary for Health, Mariam Mwaffisi, has also been crucial in garnering attention and increased resources. Largely as a result of their efforts, $\$ 50,000$ from the Ministry of Health's budget has been allocated specifically to cover the costs of fistula repairs.

Advocacy efforts are also under way to increase resources for the health sector in general. It is a testament to the openness of the government and other actors in these efforts that the Women's Dignity Project has been asked to sit on two key committees seeking greater health-sector allocations and helping to monitor poverty-reduction strategies. Participation in these committees allows the Women's Dignity Project to build alliances and help shape decisions that directly influence the lives of people living in poverty. Moreover, members of the network have labored to place the issue of fistula on the global reproductive health agenda and are collaborating with interested international organizations.

\section{Preventing Fistula Across Tanzania}

Prevention of fistula focuses on two interrelated agendas: changing family and community attitudes that place little value on girls' and women's health and improving the quality of and increasing women's access to antenatal and emergency obstetric care.

In collaboration with another Mwanza-based NGO, the Kuleana Center for Children's Rights, the Bugando Fistula Project developed a booklet entitled Haki Zangu, Je? (What About My Rights?) in 1997. This bilingual Swahili/ English booklet tells the story of Eliza, an adolescent girl who was coerced into having sex with an older man who gave her money to pay her school fees. She became pregnant, and later, suffered from fistula. Accompanied by brightly colored illustrations, the booklet concludes, "All people - including girls and women - have the right to education, good health care, freedom from violence, nutritious food, rest and relaxation, make decisions, be respected, be valued, be loved." Fifty thousand copies of this booklet were distributed to schools, health-care facilities, community groups, and religious leaders.

The Tanzania Midwives' Association works for improvement of obstetric outcomes by promoting high-quality clinical care and advances in girls' social status, particularly through delayed childbearing. To help ensure that midwives' skills are up-to-date, the association holds workshops on antenatal and obstetric care (including screening for patients at high risk of pregnancy complications and care of those experiencing prolonged labor). TAMA has also

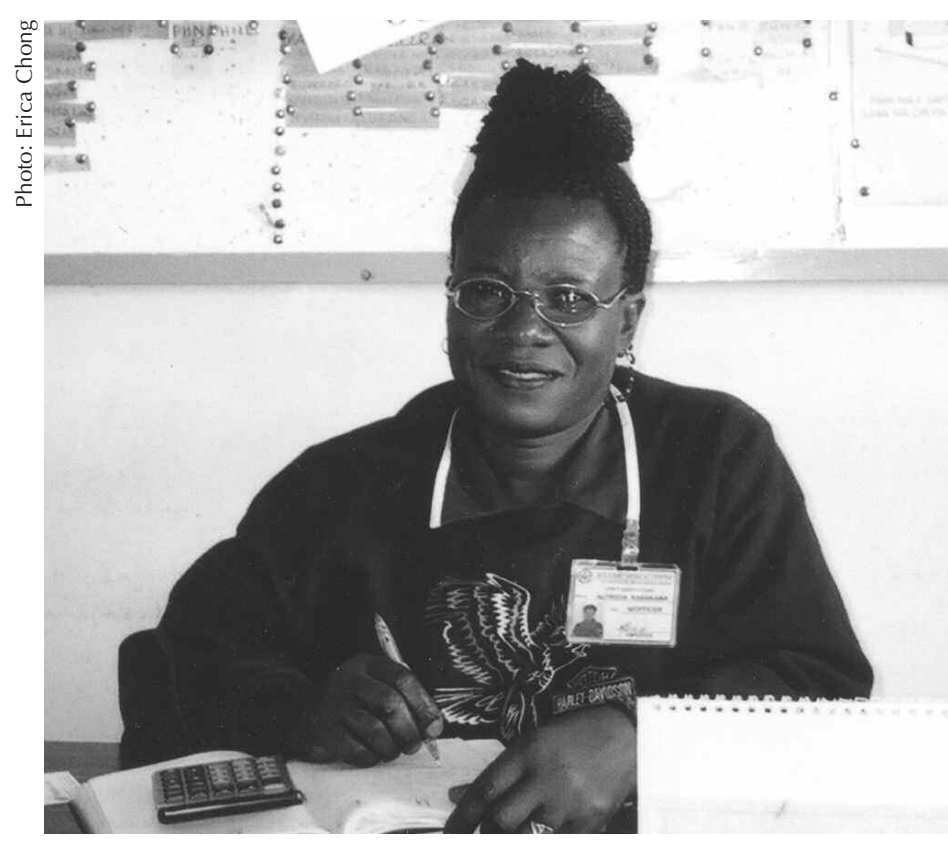

Alfreda Kabakama is chairperson of the Bugando Medical Centre branch of the Tanzania Midwives' Association (TAMA). Part of TAMA's mission is to challenge child marriage and to promote girls' and women's rights. 
successfully reached out to religious leaders with messages opposing early marriage. During a training seminar run by TAMA, local health-care workers joined with members of their communi-

\section{The cost of repairing fistula is far}

less than the loss sustained when

a woman is marginalized from

society for the rest of her life.

Moreover, starting up a fistula

program is relatively inexpensive.

ties to develop images advocating girls' and women's right to health care as part of a poster competition. One submission depicted a girl refusing the offer of marriage because she had not yet completed school; another showed men rushing a pregnant woman to a hospital for obstetric care. The Bugando Project turned some of these images into a calendar for 1999, and commissioned a local artist to adapt the images for large wall murals to be displayed in all the participating communities. Bugando staff hope that these murals exhibited in public areas such as markets and district hospitals will stimulate discussion about the reasons girls and women experience such poor reproductive health.

In collaboration with four local partners and EngenderHealth, the Women's Dignity Project is undertaking further research to shed light on the "pathways of vulnerability" to fistula. Interviews, focus-group discussions, and participatory research methods involving girls and women, family members, community members, and providers are used to document how social and economic forces put girls and women at risk; shape their labor, delivery, and postpartum experiences; and determine whether they are able to obtain access to care.
The research is uncovering such invisible factors as the opportunity costs of leaving home, a pattern whereby poor people receive treatment last; the absence of emergency community transport systems; and a lack of awareness among family decisionmakers (largely husbands and mothers-in-law) about the need to delay marriage and childbearing and to seek emergency medical care during prolonged labor. The findings will be used to develop locally appropriate ways to prevent and manage fistula throughout Tanzania by cooperating with communities and health-care providers. In a second study, the Women's Dignity Project is examining poor women's experiences of health-care services, including the impact of users' fees, barriers to access, and overall quality of care.

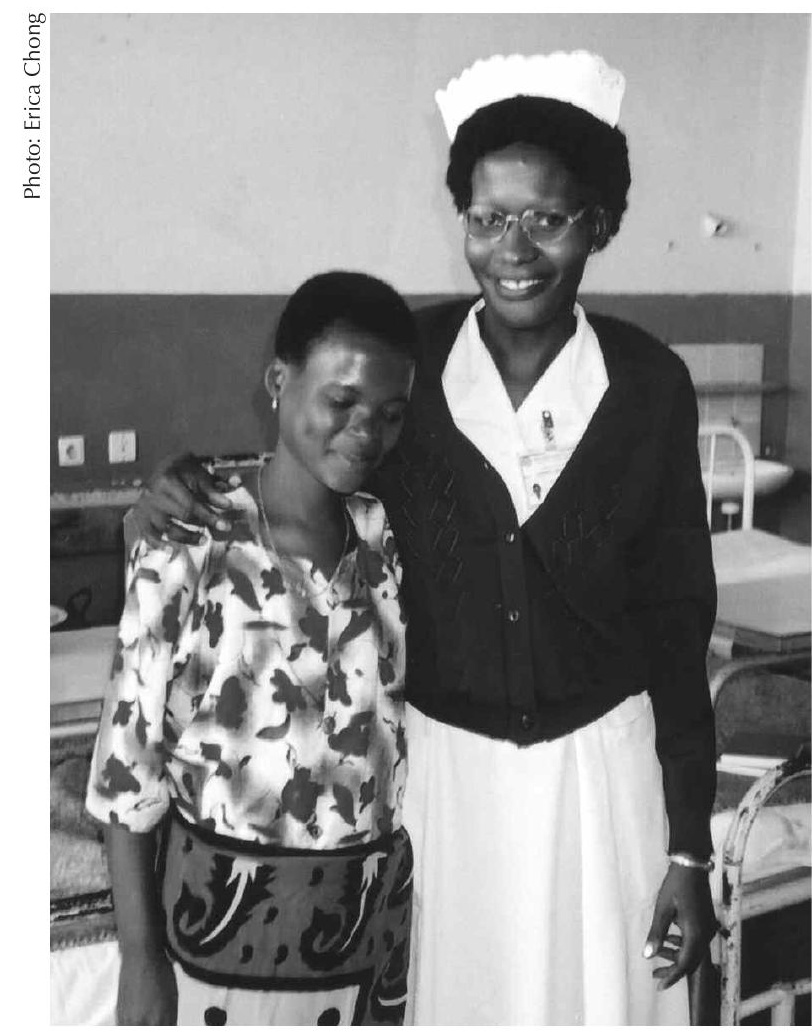

With adequate surgical staff and facilities, the great majority of fistulae can be successfully repaired or dramatically improved. 


\section{Lessons Learned}

Many concerned providers and policymakers - understanding that fistula is the result not only of inadequate emergency obstetric services but also of poverty and gender inequity-have expressed a sense of hopelessness about making fistula repairs a health-care priority. The effort to prevent the occurrence of fistula may seem even more overwhelming. The experience of the fistula network in Tanzania confirms that a partnership of hospitals, government, and communities can undertake a multidimensional effort involving economic, social, and technical interventions. The lessons from this experience offer a promising model for combating the tragedy of obstetric fistula globally.

A multidimensional approach is required to combat fistula effectively. Even those programs that start with a relatively narrow clinical emphasis on surgical repair (rather than prevention) soon face social and economic problems (for example, a shortage of surgeons, a negative impact on hospital and surgery wards, the need for thoughtful patient counseling and support, a lack of public awareness about the problem, the low priority given to women's needs, transportation constraints, reintegration challenges, and funding.).

Although fistula repairs do not have a 100 percent success rate, the great majority of cases can be successfully repaired or dramatically improved if the repair performed is of high quality. The positive difference a successful repair makes in a woman's life is enormous.

Policymakers, surgeons, and donors who have viewed fistula as an overwhelming and immutable problem are often inspired by individual stories to tackle the issue and to commit their resources to the task.

Fistula repair is a good economic investment: The cost-about \$250-is far less than the loss sustained when a woman is marginalized from society for the rest of her life. Moreover, starting up a fistula program is relatively inexpensive.

The widespread incidence of fistula reflects the problems poor women face generally; efforts to reduce the incidence of the condition can serve to build awareness of women's right to healthcare and of gender issues of power.

\section{References}

Bangser, Maggie et al. 1999. "A comprehensive approach to vesico-vaginal fistula: A project in Mwanza, Tanzania." in Safe Motherhood Initiatives: Critical Issues. Eds. Marge Berer and T.K. Sundari Ravindran. Oxford: Blackwell Science. Pp.157-165.

Mpangile, Gottlieb S. et al. 1993. "Factors associated with induced abortion in public hospitals in Dar es Salaam, Tanzania." Reproductive Health Matters 2: 21-31.

National Bureau of Statistics of Tanzania (NBS) and Macro International. (MI). 2000. Tanzania Reproductive and Child Health Survey 1999. Dar es Salaam and Calverton, MD: NBS and MI.

Population Reference Bureau (PRB). 2000. The World's Youth 2000. Washington, DC: PRB.

2001. Youth in Sub-Saharan Africa: A Chartbook on Sexual Experience and Reproductive Health. Washington, DC: PRB.

2002. 2002 World Population Data Sheet. Washington, DC: PRB.

The POLICY Project (TPP). Maternal and Neonatal Program Effort Index: Tanzania. <http:// www.policyproject.com/pubs/MNPI/Tanzania_MNPI.pdf>. Accessed 11 July 2003.

United Nations Development Programme (UNDP). 2003. Human Development Report 2003. New York: Oxford University Press.

UNFPA (United Nations Population Fund). 2003. The Second Meeting of the Working Group for the Prevention and Treatment of Obstetric Fistula. New York: UNFPA.

Women's Dignity Project (WDP). 2002. Tanzania Fistula Survey 2001. Dar es Salaam: WDP.

World Bank. 2003. Country Data: Tanzania at a Glance. <http//:www.worldbank.org/ data/countrydata/countrydata.html>. Accessed 11 July 2003. 


\section{Resumen en Español}

La fístula obstétrica es una complicación del parto con consequencias devastadoras que afecta a entre 50.000 y 100.000 niñas y mujeres cada año, principalmente en África y el Sur de Asia. La presión prolongada de la cabeza del bebé contra la pelvis de la madre durante un parto obstruido interrumpe el flujo de sangre a los tejidos vecinos, causando una perforación entre la vejiga y la vagina, y/o entre la vagina y el recto. Las niñas o mujeres afligidas por la fístula obstétrica sufren pérdidas contínuas de orina y materia fecal a través de la vagina, además de haber sufrido la muerte de su criatura, en la mayoría de los casos, durante un parto prolongado y obstruido.

Entre las causas de la fístula obstétrica se encuentran los altos índices de desnutrición, el embarazo y parto precoz, la falta de acceso a la atención obstétrica de emergencia, los altos costos de atención médica y transporte, las situaciones que le niegan a la mujer el poder para decidir cuestiones que afectan su salud, y la falta de información sobre la salud. La mayoría de las mujeres afligidas por la fístula son rechazadas por sus esposos y por la comunidad en general, y se les suele echar la culpa por su condición. Aunque casi todos los tipos de fístula se pueden reparar con cirugía, la mayoría de las mujeres afectadas no están conscientes de esta posibilidad.

Esta edición de Quality/Calidad/Qualité describe una asociación creada para combatir la fístula obstétrica en Tanzania. Uno de los principales hospitales del país, varias ONG, y el gobierno cooperan en la ejecución de un extenso programa de reparación quirúrgica, prevención, e investigación y actividades sobre políticas relevantes.

Al Bugando Medical Centre (BMC), un pequeño grupo de profesionales impulsó las gestiones necesarias para obtener capacitación quirúrgica, establecer los protocolos clínicos y de gestión, y recaudar los fondos para equipos y camas. De las 645 reparaciones practicadas en el BMC hasta la fecha, $74 \%$ fueron exitosas, $5 \%$ fracasaron, y $20 \%$ fueron parcialmente exitosas. El personal del centro considera que la problemática social de los pacientes es tan importante como la de salud. Además de la atención clínica, las enfermeras proporcionan orientación y apoyo a sus pacientes. El reclutamiento y la capacitación de nuevos cirujanos y la movilización de recursos para cubrir los costos son desafíos permanentes para el centro (el costo promedio por paciente es US\$250, pero el BMC no cobra por sus servicios).

El BMC colabora con el gobierno, la Women's Dignity Project (WDP, o Proyecto Dignidad de la Mujer) y la Tanzania Midwives' Association (TAMA, o Asociación de Parteras de Tanzania) para: mejorar el conocimiento público sobre la posibilidad de reparar las fístulas; identificar mujeres que necesitan la operación; reducir la frecuencia de la fístula a través de un mejor acceso a los servicios obstétricos de emergencia; promover la importancia de la salud y los derechos de las mujeres; desarrollar planes estratégicos para gestionar y facilitar la atención médica; y movilizar recursos. El gobierno ha destinado fondos del presupuesto público a la reparación de fístulas y ha ayudado a establecer un sistema nacional de derivaciones para mujeres afectadas. TAMA realiza actividades de educación comunitaria sobre qué es la fístula, dónde se puede obtener atención, y la importancia de obtener exámenes obstétricos y postergar el matrimonio con el fin de mejorar la situación de las mujeres jóvenes. WDP ha realizado estudios de los servicios de reparación de fístulas en los hospitales de Tanzania, colabora con el gobierno en comités de monitoreo del sector salud, y realiza investigaciones sobre actitudes hacia la fístula al nivel comunitario.

Lecciones aprendidas: (1) Los programas de fístula tienen que atender a cuestiones sociales tanto como médicas; (2) la mayoría de las reparaciones son exitosas y tienen un impacto tremendo en la vida de la mujer afectada; (3) crear un programa para fístulas cuesta relativamente poco; y (4) los programas para atender a fístulas sirven como vehículos para el diálogo sobre género y pobreza. 


\section{Résumé en Français}

La fistule obstétrique est une lésion dévastatrice qui se produit lors de l'accouchement et qui atteint environ 50000 à 100000 filles et femmes chaque année, principalement en Afrique et en Asie méridionale. La pression prolongée de la tête de l'enfant sur le pelvis de la mère pendant un accouchement difficile coupe la circulation du sang qui alimente les tissus environnants, ce qui finit par entraîner la formation d'un trou entre la vessie et le vagin et/ou entre le rectum et le vagin. Chez les filles et les femmes souffrant d'une fistule obstétrique, les urines et/ou les matières fécales s'écoulent continûment du vagin, et presque toutes ces filles et femmes perdent leur enfant pendant I'accouchement dystocique.

Certaines des causes sous-jacentes de la fistule obstétrique incluent des taux élevés de malnutrition, le jeune âge de procréation, I'accès insuffisant aux soins obstétricaux d'urgence, les frais de traitement et de transport inabordables, le manque de pouvoir décisionnel des femmes en ce qui concerne leur santé ainsi que le manque $d^{\prime}$ information sur la santé. La plupart des femmes souffrant d'une fistule sont rejetées par leur mari, évitées par les membres de leur communauté, et blâmées pour leur état. Bien qu'il soit possible de réparer chirurgicalement la plupart des fistules, la majorité des femmes atteintes ignore l'existence d'un traitement.

Cette édition de Quality/Calidad/Qualité décrit un partenariat formé pour lutter contre la fistule obstétrique en Tanzanie. Un des plus grands hôpitaux du pays, plusieurs ONG et le gouvernement collaborent à un vaste programme comprenant la réparation chirurgicale des fistules, leur prévention ainsi que la recherche et des activités en matière de politique de santé.

Au Bugando Medical Centre (BMC), un petit groupe de professionnels a organisé la formation chirurgicale, établi des protogcoles cliniques et de gestion médicale des patientes et collecté des fonds pour l'achat d'instruments et de lits. Des 645 réparations faites à ce jour au BMC, 74 pour cent ont réussi, 5 pour cent ont échoué et 20 pour cent ont partiellement réussi. Le personnel accorde la même priorité aux besoins sociaux des patientes qu'à leurs problèmes médicaux. En plus des soins cliniques, les infirmiers donnent aux patientes des conseils personnalisés. Les défis permanents incluent le recrutement et la formation de nouveaux chirurgiens ainsi que la mobilisation des ressources pour couvrir les frais (le coût moyen par patiente est de $\$ 250$, mais les services du BMC sont gratuits).

BMC collabore avec le gouvernement, le Projet concernant la dignité des femmes (WDP, Women's Dignity Project) et l'Association des sages-femmes de la Tanzanie (TAMA, Tanzania Midwives' Association) pour sensibiliser le public à la possibilité de réparation, identifier les femmes ayant besoin $d^{\prime}$ une opération, réduire la fréquence des fistules grâce à un plus grand accès aux services obstétricaux d'urgence, promouvoir l'importance de la santé et des droits des femmes, élaborer des plans stratégiques pour gérer et faciliter les soins, et mobiliser les ressources. Le gouvernement a affecté des fonds à la réparation des fistules dans son budget et aidé à établir un système de référence national. Au niveau de la collectivité, TAMA informe le public sur la fistule, sur l'emplacement des centres de soin spécialisés, ainsi que sur l'importance des soins obstétricaux et du mariage retardé dans le cadre d'une stratégie d'amélioration du statut des filles. WDP a mené une enquête auprès des services de réparation des fistules des hôpitaux tanzaniens, collaboré avec le gouvernement au sein de comités de révision du secteur sanitaire et fait de la recherche sur les attitudes communautaires ayant une incidence sur la fistule.

Leçons tirées : (1) Les programmes de lutte contre la fistule doivent aborder aussi bien les problèmes sociaux que médicaux; (2) la plupart des réparations réussissent, changeant énormément la vie des femmes; (3) relativement peu de fonds sont nécessaires pour démarrer un programme de lutte contre la fistule; et (4) les programmes de lutte contre la fistule permettent de générer un débat plus large sur les questions de genre et de pauvreté. 


\section{About the Authors}

Thoraya Ahmed Obaid is the Executive Director of UNFPA, the United Nations Population Fund, the world's largest multilateral source of population assistance. UNFPA is spearheading a global Campaign to End Fistula.

Erica Chong is a staff assistant in the International Programs Division of the Population Council in New York.

\section{Production Staff}

Editor: Debbie Rogow

Research and editorial assistant:

Michelle Skaer

Project editor: Karen Tweedy-Holmes

Designer: Mike Vosika

Translators: Paul Constance (Spanish) and Jeannette Ndong (French)

\section{Advisory Group}

Delia Barcelona

Gary Barker

Laura Laski

Carmen Barroso

Ann Leonard

Judith Bruce

Batya Elul

Susana Galdos

Kirrin Gill

Françoise Girard

Nicole Haberland

Katherine Kurz
Ann McCauley

Liz McGrory

Manisha Mehta

Suellen Miller

Saumya Ramarao

Julie Reich

Ann Starrs

Cynthia Steele

\section{Acknowledgments}

Erica Chong thanks the dedicated staff at the Bugando Medical Centre, especially Elizabeth Mach and Yasinta Mkama, for providing valuable information and for facilitating data collection. She is indebted to the girls and women who openly shared their views and experiences with fistula.

We invite your comments on Quality/Calidad/Qualité. If you would like to be included on our mailing list, please send an e-mail to: qcq@popcouncil.org. Most past editions are available online at $<w w w . p o p c o u n c i l . o r g / p u b l i c a t i o n s / q c q / d e f a u l t . h t m>$. The following are also available in print; single or multiple copies may be ordered by e-mail:

Celebrating Mother and Child on the Fortieth Day: The Sfax Tunisia Postpartum Program (English only), no. 1, 1989.

Man/Hombre/Homme: Meeting Male Reproductive Health Care Needs in Latin America (English, Spanish), no. 2, 1990.

The Bangladesh Women's Health Coalition (English only), no. 3, 1991.

By and For Women: Involving Women in the Development of Reproductive Health Care Materials (English, Spanish), no. 4, 1992.

Gente Joven/Young People: A Dialogue on Sexuality with Adolescents in Mexico (English, Spanish), no. 5, 1993.

The Coletivo: A Feminist Sexuality and Health Collective in Brazil (English, Portuguese, Spanish), no. 6, 1995.

Doing More with Less: The Marie Stopes Clinics of Sierra Leone (English only), no. 7, 1995.

Introducing Sexuality within Family Planning: Three Positive Experiences from Latin
America and the Caribbean (English, Spanish), no. 8, 1997.

Using COPE to Improve Quality of Care: The Experience of the Family Planning Association of Kenya (English, Spanish), no. 9, 1998.

Alone You Are Nobody, Together We Float: The Manuela Ramos Movement (English, Spanish), no. 10, 2000.

From Patna to Paris: Providing Safe and Humane Abortion (English only), no. 11, 2001.

Universal Sexuality Education in Mongolia: Educating Today to Protect Tomorrow (English only), no. 12, 2002.

What about Us? Bringing Infertility into Reproductive Health Care (English only), no. 13, 2002.

"My Father Didn't Think This Way": Nigerian Boys Contemplate Gender Equality (English, French), no. 14, 2003.

Linking Reproductive Health to Social Power: Community Health Workers in Belize and Pakistan (English only), no. 15, 2004. 
Q/C/Q No. 16

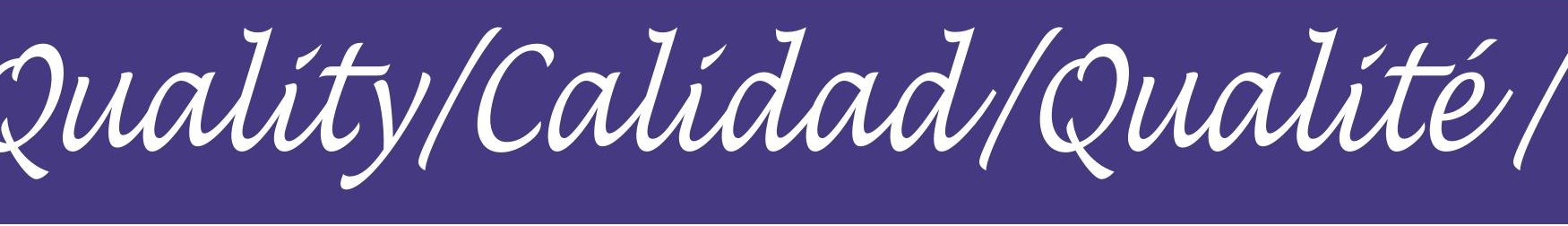

